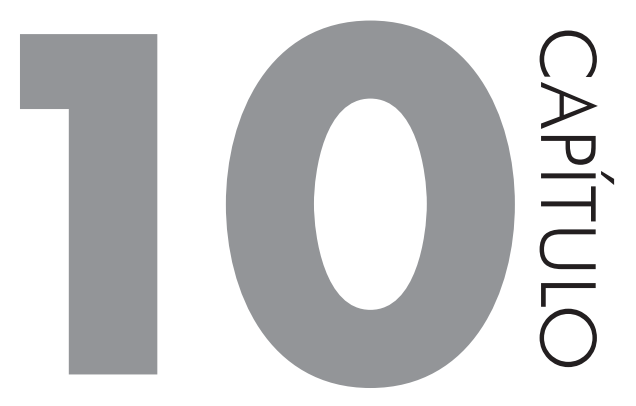

\title{
ORDEM DOS CLITIICOS PRONOMINAIS NO PORTUGUÊS DE SÃO TOMÉ E NO PORTUGUÊS DE MOÇAMBIQUE
}

\section{SILVIA RODRIGUES VIEIRA/ MARIA DE FÁTIMA VIEIRA}

\section{INTRODUÇÃO: DELIMITANDO OS PROPÓSITOS DESTE CAPÍTULO}

O tema da colocação pronominal configura-se como importante tópico morfossintático para a diferenciação entre as variedades vernaculares do Português do Brasil (PB) e do Português Europeu (PE). Considerando o contexto de interações espontâneas e, portanto, supostamente sem maior controle em termos de monitoração estilística, sabe-se que colocar o pronome átono antes ou depois do verbo em início de oração ou em contextos sem a presença de algum elemento gramatical do tipo proclisador - como em me dá um cafezinho versus dá-me um cafezinho ou, ainda, em o texto se refere versus o texto refere-se - constitui, sem dúvida, expressão suficiente para a definição identitária do falante quanto ao pertencimento a uma das duas referidas variedades.

Em conjunto com o tratamento da concordância verbal e nominal (Cf. VIEIRA; BRANDÃO, 2014), objeto dos dois capítulos anteriores, descrever a colocação pronominal em variedades africanas do Português segundo os pressupostos sociolinguísticos (Cf. WEINREICH; LABOV; HERZOG, 1968; LABOV, 1972) é de fundamental relevância para a observação de propriedades linguísticas que permitam definir o estatuto de cada variedade do Português, 
bem como discutir as motivações, internas ou externas à língua, para essa definição. Retomando o que já foi proposto, não só na apresentação e no prefácio deste livro, mas também nos textos precedentes, somente a descrição detalhada de dados de cada uma das variedades do Português permitirá traçar hipóteses para a configuração do chamado continuum afro-brasileiro (Cf. PETTER, 2007, 2015; AVELAR; GALVES, 2014).

Com o propósito de colaborar com o fornecimento de informações para tal descrição, o presente texto organiza-se da seguinte forma:

(i) primeiramente (Seção 2), apresenta, de forma muito sintética, as tendências de colocação pronominal verificadas para o PB e o PE, sobretudo as observadas (Cf. dissertação de Mestrado de CORRÊA, 2012; tese de Doutorado de VIEIRA, 2016) em entrevistas sociolinguísticas recolhidas entre 2009 e 2011 no âmbito do Banco de dados do Projeto Estudo comparado dos padrões de concordância em variedades africanas, brasileiras e europeias do Português, doravante Corpus Concordância (www.concordancia.letras.ufrj.br);

(ii) em seguida (Seção 3), reúne informações de estudos variacionistas sobre a ordem dos clíticos pronominais em duas variedades urbanas do Português na África, a de São Tomé (PST) - na amostra constituída por Tjerk Hagemeier e disponibilizada pelo Projeto VAPOR, do Centro de Linguística da Universidade de Lisboa (cf. tese de doutorado de VIEIRA, 2016) - e a de Maputo/Moçambique (PM) - seja nas entrevistas do Projeto Panorama do Português Oral de Maputo/PPOM, em banco de dados organizado por Christopher Stroud e Perpétua Gonçalves (1997), doravante Corpus PPOM (Cf. tese de doutorado de VIEIRA, 2002), seja em uma pequena amostra coletada ${ }^{1}$ de entrevistas sociolinguísticas realizadas recentemente, em 2016, por Silvia Rodrigues Vieira e Karen Cristina da Silva Pissurno, doravante Corpus Moçambique; e

(iii) após uma breve sistematização dos resultados obtidos (Seção 4), o texto oferece reflexões para a delimitação da natureza e das propriedades das variedades do Português (Seção 5). Para tanto, leva em consideração, sobretudo, a abordagem comparativa dessas variedades, considerando não só as motivações linguísticas para a variação, mas também a situa-

1 A coleta dos dados foi realizada pela graduanda da Faculdade de Letras da UFRJ, Amanda Carolina de Oliveira Santos, por ocasião do desenvolvimento de seu trabalho de conclusão de curso, em 2017, que versou sobre o tema da colocação pronominal. 
ção de multilinguismo nas sociedades africanas em questão e na formação do Português do Brasil.

Espera-se, assim, contribuir não só com a descrição das variedades do Português, mas também com o avanço científico no sentido de explicar a complexa rede de fatores, de natureza linguística e extralinguística, que explicam a formação do perfil das variedades de uma língua.

\section{COLOCAÇÃO PRONOMINAL NAS VARIEDADES BRASILEIRA E EUROPEIA DO PORTUGUÊS}

Considerando os estudos já referidos sobre o PB e o PE com amostras contemporâneas de fala, pode-se afirmar, em linhas gerais, que a preferência na fala brasileira, quando se trata de construções com apenas uma forma verbal, é a realização pré-verbal ( europeia, que teria por preferência a realização pós-verbal (dá-me o cafezinho, ele referiu-se ao livro $)^{2}$.

$\mathrm{Na}$ variedade falada no Brasil (Cf. VIEIRA, 2002; CORRÊA, 2012; VIEIRA, 2016), ocorre, na realidade, uma regra de colocação semicategórica, segundo a tipologia de Labov (2003), regra que se concretiza na quase totalidade dos dados, de $96 \%$ a $99 \%$ das ocorrências, e abrange, em termos qualitativos, amplo espectro das construções estruturais ${ }^{3}$. Nesse sentido, cabe registrar que a variante pós-verbal fica restrita no $\mathrm{PB}$, em termos linguísticos, a construções particulares, como, por exemplo, as que incluem os clíticos $o, a(s)$ seguidos de infinitivo (como em encontrá-lo) e se em estruturas de natureza indeterminadora (como em trata-se de). Ademais, em termos extralinguísticos, essas construções acabam por ser praticadas por grupos sociais também específicos, sobretudo os com maior grau de escolaridade ou acesso à cultura de escrita letrada, e em situações de interação supostamente mais monitoradas ou controladas.

2 Embora não se negue a variante mesoclítica (dar-me-ia), o presente artigo não a prioriza pelos seguintes motivos: (1) a mesóclise não foi registrada em diversas amostras ora em análise, o que indica sua especialização de uso, muito vinculada até onde se sabe à modalidade escrita e a gêneros textuais específicos; (2) em termos estruturais, essa variante também fica restrita a formas de futuro simples, o que também desfavorece a comparabilidade dos resultados gerais.

3 VIEIRA (2014) apresenta análise detalhada do estatuto semicategórico ou variável não só da ordem dos clíticos pronominais, mas também da concordância verbal, tomando por base as variedades brasileira e europeia do Português. 
VIEIRA (2016) investigou o fenômeno valendo-se de entrevistas sociolinguísticas - recolhidas entre 2009 e 2011 no âmbito do Corpus Concordância realizadas com 36 informantes em cada variedade, distribuídos por sexo, três faixas etárias (18-35 anos, 36-55 anos e 56-75 anos) e três níveis de escolaridade (fundamental: 5 a 8 anos; médio: 9 a 11 anos; superior).

Em termos de distribuição geral dos dados, o estudo constata uma diferença fundamental entre as variedades: o PE apresenta ênclise categórica em início de oração, enquanto o PB registra alta produtividade de próclise (91\%).

Mesmo excetuando o início absoluto de oração, as diferenças também são relevantes, como demonstram os resultados representados na Figura 1:

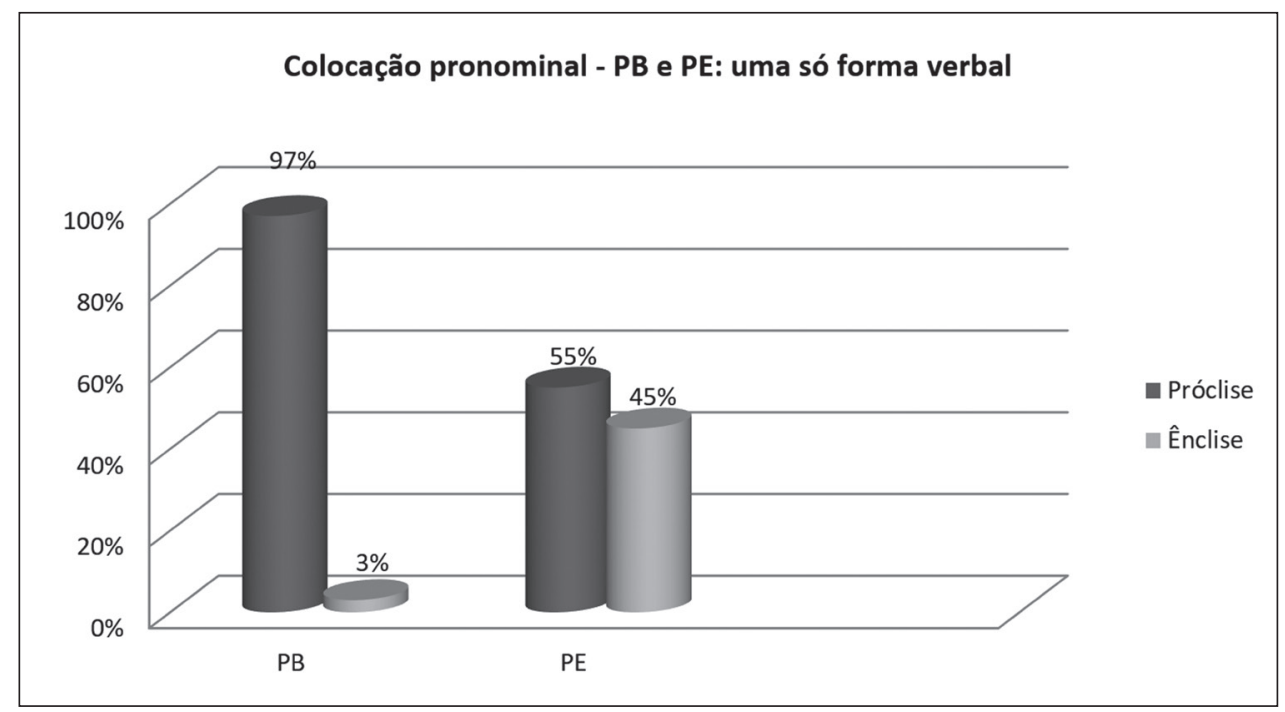

Figura 1 A ordem dos clíticos pronominais em construções com uma só forma verbal na fala do PB e do PE em contexto não inicial de oração segundo VIEIRA (2016)

Fonte: Vieira (2016: 121)

Como se pode observar, os resultados confirmam as referidas tendências do PB: do total de 1.088 ocorrências de pronomes átonos em posição não inicial, a variante pré-verbal foi a opção preferencial (1.053 ocorrências, 97\%); a variante pós-verbal ficou restrita a apenas 35 dados, o que corresponde a 3\%. De outro lado, os dados europeus distribuem-se regularmente entre as variantes pré e pós-verbal. Do total de 2.664 ocorrências, registrou-se a variante proclítica em 1.453 dados (55\%) e a enclítica em 1.211 (45\%).

A autora resume, na forma de um quadro-síntese, os principais resultados a que chegou com a descrição do PB, do PE e do PST. Reproduz-se, no Quadro 1, o que foi verificado para as duas primeiras variedades: 
Quadro 1 Sistematização da ordem dos clíticos pronominais em construções com uma só forma verbal na fala do PB e do PE segundo VIEIRA (2016)

\begin{tabular}{|c|c|c|}
\hline $\begin{array}{l}\text { CONSTRUÇÕES COM UMA } \\
\text { SÓ FORMA VERBAL }\end{array}$ & PB & PE \\
\hline Próclise em início absoluto & Presente e produtiva (91\%) & Ausente $(0 \%)$ \\
\hline $\begin{array}{l}\text { Distribuição das variantes } \\
\text { nos demais contextos }\end{array}$ & $\begin{array}{l}\text { Próclise }=97 \% \\
\text { Ênclise }=3 \%\end{array}$ & $\begin{array}{l}\text { Próclise }=55 \% \\
\text { Ênclise }=45 \%\end{array}$ \\
\hline $\begin{array}{l}\text { Estatuto da regra segundo } \\
\text { Labov (2003) }\end{array}$ & Semicategórica & Variável \\
\hline $\begin{array}{l}\text { Variáveis extralinguísticas: } \\
\text { condicionamento externo }\end{array}$ & $\begin{array}{l}\text { Maior uso de ênclise por indivíduos } \\
\text { com mais instrução e idade. }\end{array}$ & $\begin{array}{l}\text { Não houve relevância estatística de } \\
\text { variáveis externas. }\end{array}$ \\
\hline Variáveis linguísticas & $\begin{array}{l}\text { Registro de ênclise sobretudo com } \\
\text { acusativos de } 3^{\text {a }} \text { pessoa (frequente- } \\
\text { mente combinados com infinitivos), } \\
\text { alguns casos de Ihe e de se, em estra- } \\
\text { tégia de indeterminação; presença de } \\
\text { expressões cristalizadas. }\end{array}$ & $\begin{array}{l}\text { Variáveis estatisticamente relevantes: } \\
\text { presença e natureza do elemento an- } \\
\text { tecedente; tempo e modo verbal; dis- } \\
\text { tância entre o clítico e um elemento } \\
\text { antecedente. }\end{array}$ \\
\hline Efeito proclisador & $\begin{array}{l}\text { Não se aplica. } \\
\text { Próclise verificada em qualquer con- } \\
\text { texto, inclusive em início absoluto. }\end{array}$ & $\begin{array}{l}\text { Efeito proclisador verificado (embora } \\
\text { não de forma categórica): proclisa- } \\
\text { dores (partículas de negação; con- } \\
\text { junções subordinativas; preposições } \\
\text { para, de; operadores de foco ou ad- } \\
\text { vérbios (também, já, atẽ) }{ }^{4} \text { versus não } \\
\text { proclisadores (conjunções coordena- } \\
\text { tivas, sujeitos, adjuntos adverbiais, } \\
\text { complementos preposicionados) cla- } \\
\text { ramente delimitados. }\end{array}$ \\
\hline
\end{tabular}

Fonte: Vieira (2016: 171-172), com adaptação

O quadro acima permite afirmar que os parâmetros de colocação do PB e do PE apresentam diferenças relevantes do ponto de vista qualitativo e quantitativo.

4 Cabe enfatizar que se apresentam, aqui, tão-somente os itens verificados na amostra analisada por Vieira (2016). Para maior detalhamento da funcionalidade de elementos proclisadores no PE, recomenda-se a consulta ao capítulo "Posição dos pronomes clíticos", de Ana Maria Martins, na Gramática do Português (Cf. MARTINS, 2013). 
No $\mathrm{PB}$, o perfil do informante que produziu os poucos dados de ênclise correlaciona-se, possivelmente, a maior idade e, secundariamente, a maior nível de instrução. No que se refere à influência de variáveis linguísticas, Vieira afirma:

os clíticos acusativos, principalmente com o verbo no infinitivo, e o pronome "se" seriam os contextos em que a posição enclítica mais ocorreria. Além disso, houve exemplos de construções cristalizadas (como "chama-se", "deu-lhe", "ganhou-lhe" e "parece-me") que concretizaram a colocação enclítica. (VIEIRA, 2016, p. 173)

De outro lado, no PE, a autora observa, nos contextos não iniciais de oração, ora próclise, ora ênclise, o que, nas palavras da autora, configura uma diferença paramétrica fundamental motivada efetivamente por restrições de ordem sintática. Não tendo havido seleção de qualquer variável extralinguística, resumem-se os condicionamentos estruturais da seguinte forma:

De toda forma, é nítida a atuação diferenciada do grupo dos elementos que atuaram como proclisadores versus o grupo dos elementos que não atuaram como proclisadores, o que valida a interpretação de que o PE, embora em todos os casos registre variação entre as variantes pré e pós-verbal, permite a generalização de que existem contextos de (i) ênclise categórica (início absoluto de oração e de período); (ii) próclise altamente favorecida (partículas de negação, elementos subordinativos, preposições - para, de, por e sem - e operadores de foco); e (iii) próclise altamente desfavorecida (adjuntos adverbiais, complementos preposicionados, preposições - a e em -, sujeitos e conjunções coordenativas). (VIEIRA, 2016, p. 174)

No caso de construções com mais de uma forma verbal (perífrases diversas, como as temporais, aspectuais e modais), o PB admitiria como opção preferencial a posição do clítico interna ao complexo, o que corresponderia, na realidade, a uma próclise à segunda forma verbal, como fica patente em exemplos do tipo você pode amanhã me dizer o que é preciso. As outras posições nos complexos também ficam restritas a determinadas estruturas, como com o clítico se indeterminador antes da primeira (não se pode dizer...) ou ainda com o clítico o, a (s) após a segunda forma no infinitivo (pode encontrá-lo $)^{5}$.

5 Os resultados relativos a dados contemporâneos, de que se vale o presente artigo, confirmam, em certa medida, tendências propostas na vasta produção bibliográfica sobre o tema, cuja revisão não cabe nos propósitos limitados deste artigo. Vale destacar, aqui, que os estudos pioneiros da colocação pronominal não só apontaram as inovações brasileiras (Cf., por exemplo, PAGOTTO, 1992), mas também buscaram explicar fatores relacionados às motivações linguísticas, como as de natureza fonético-fonológica, demonstrando a correlação entre a ênclise e os 
Em termos de distribuição geral dos dados de clíticos em estruturas com mais de uma forma verbal, o estudo também constata nítidas diferenças entre as variedades. A Tabela 1 e a Figura 2 permitem observar a produtividade das variantes, que controlam a posição superficial do pronome átono $(\mathrm{cl})$ em relação à primeira (v1) e à segunda forma (v2) verbais, além da presença ou não de outro elemento interveniente no complexo (x).

Tabela 1 A ordem dos clíticos pronominais em complexos verbais na fala do PB e do PE segundo VIEIRA (2016)

\begin{tabular}{|l|c|c|c|c|c|c|c|c|c|c|c|}
\hline \multicolumn{10}{|c|}{ COLOCAÇÃO PRONOMINAL: PB E PE } \\
\hline Variedades & \multicolumn{2}{|c|}{$c l$ v1 v2 } & \multicolumn{2}{|c|}{ v1-cl x v2 } & \multicolumn{2}{c|}{ v1 (-) cl v2 } & \multicolumn{2}{|c|}{ v1 x cl v2 } & \multicolumn{2}{|c|}{ v1 v2 cl } & Total \\
\hline PB & 8 & $2 \%$ & 0 & $0 \%$ & 289 & $78 \%$ & 66 & $18 \%$ & 6 & $2 \%$ & 369 \\
\hline PE & 246 & $37 \%$ & 68 & $11 \%$ & 172 & $27 \%$ & 75 & $12 \%$ & 81 & $13 \%$ & 642 \\
\hline
\end{tabular}

Fonte: Vieira (2016: 176), adaptado

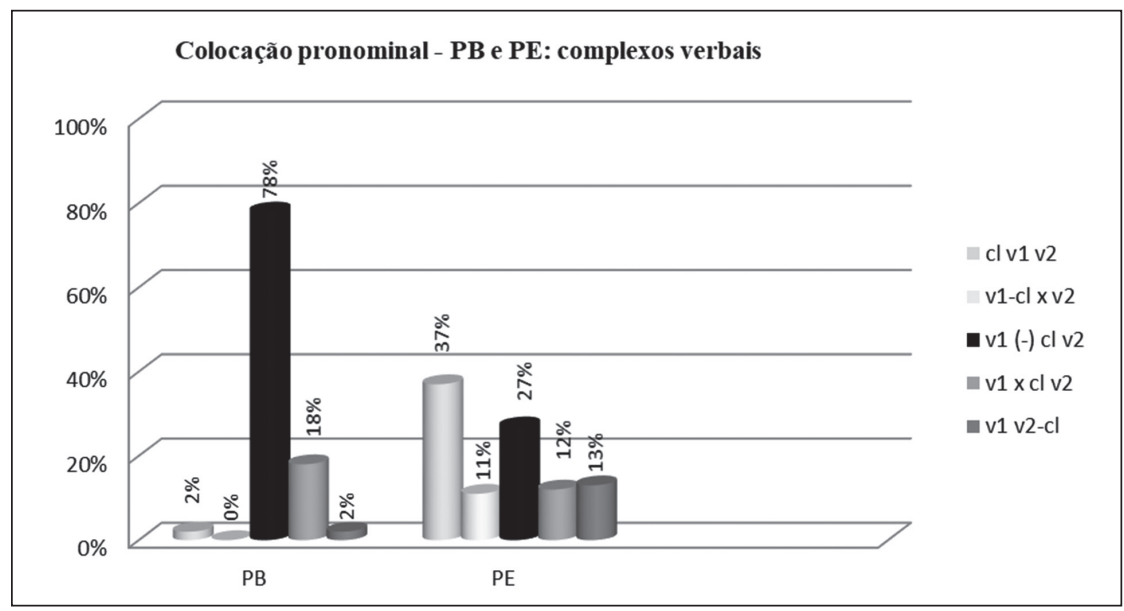

Figura 2 A ordem dos clíticos pronominais em complexos verbais do PB e do PE segundo VIEIRA (2016)

Fonte: Vieira (2016: 176), adaptado

Da comparação dos resultados com as amostras brasileira e europeia, podem-se atestar, mais uma vez, marcantes diferenças entre as variedades. Os

pronomes com onset silábico (Cf. NUNES, 1993), e as sociais, como a vinculação da ênclise à fala monitorada de pessoas com alto nível de escolaridade (Cf. LOBO, 1992). 
clíticos no PB distribuem-se basicamente pela posição imediatamente antecedente a v2 - em estruturas com (18\%) ou sem (78\%) elementos intervenientes, como, respectivamente, em pode amanhã me dizer e pode me dizer -, totalizando $96 \%$ dos casos. Poucas ocorrências de clíticos em outras posições $-2 \%$ antes de v1 (aqui se pode dizer) e 2\% após v2 (pode encontrá-lo) - foram registradas. Observa-se que essas posições se restringem basicamente ao tipo de clítico; na realidade, a ligação sintática a v1 fica condicionada à estrutura indeterminadora com o pronome se; e a ênclise a v2 ao pronome acusativo de $3^{a}$ pessoa, manifesto na forma lo e variantes. Chama a atenção, ainda, a ausência de dados de clíticos antes de elemento interveniente, posição que permitiria a interpretação de ênclise a v1 (como em começou-me a dizer; pode- me amanhã dizer).

No PE, verificou-se efetiva distribuição dos dados por todas as variantes controladas, da seguinte forma: a próclise a v1 foi registrada em $37 \%$ dos dados, seguida pelo clítico imediatamente após essa forma verbal, seja em construções sem elemento interveniente (27\%), seja na presença desses elementos $(11 \%)$. Vale ressaltar que esta última variante, que configura caso efetivo de ênclise à primeira forma verbal do complexo, nem sequer foi registrada no PB. No PE, além da variante enclítica a v1, também foi registrada com produtividade $(13 \%)$ a ênclise à segunda forma verbal. No que se refere às ocorrências da variante v1 x cl v2 (12\%), Vieira (2016) enfatiza que elas ocorreram,

em geral, com os complexos verbais que já possuem algum elemento integrante em seu interior - o "que" e o "de" (ter que/de), por exemplo -, mostrando que, diferentemente do $\mathrm{PB}$, não ocorreria uma próclise a v2, mas uma ênclise ao elemento que atua como proclisador interno ao complexo, como em "tem que se fazer". (VIEIRA, 2016, p. 177)

Embora não se disponha de espaço nos limites do presente artigo para detalhar as construções registradas na amostra de complexos verbais, é preciso deixar claro que, nos dados da variedade europeia, houve efetivamente elementos condicionadores das variantes. A esse respeito, pode-se resumidamente afirmar que a presença de elementos proclisadores, embora favoreça a próclise ao complexo (que me pode dizer), não apresenta atuação categórica, tendo havido também ênclise à primeira forma verbal (em complexos com gerúndio e particípio, como em que vem-me visitando ou que tinha-me encontrado) ou à segunda (em complexos com infinitivo, como em que pode dizer-me). Não havendo elemento proclisador, a ênclise - a v1 ou a v2 - constitui opção natural. Clíticos imediatamente antes de v2 ficam restritos a complexos com ter quelde - o que não permite afirmar uma efetiva próclise a v2. 
Diante do detalhamento dos resultados, a Figura 3 permite visualizar o comportamento de cada variedade em relação ao verbo que está efetivamente hospedando o clítico em cada caso.

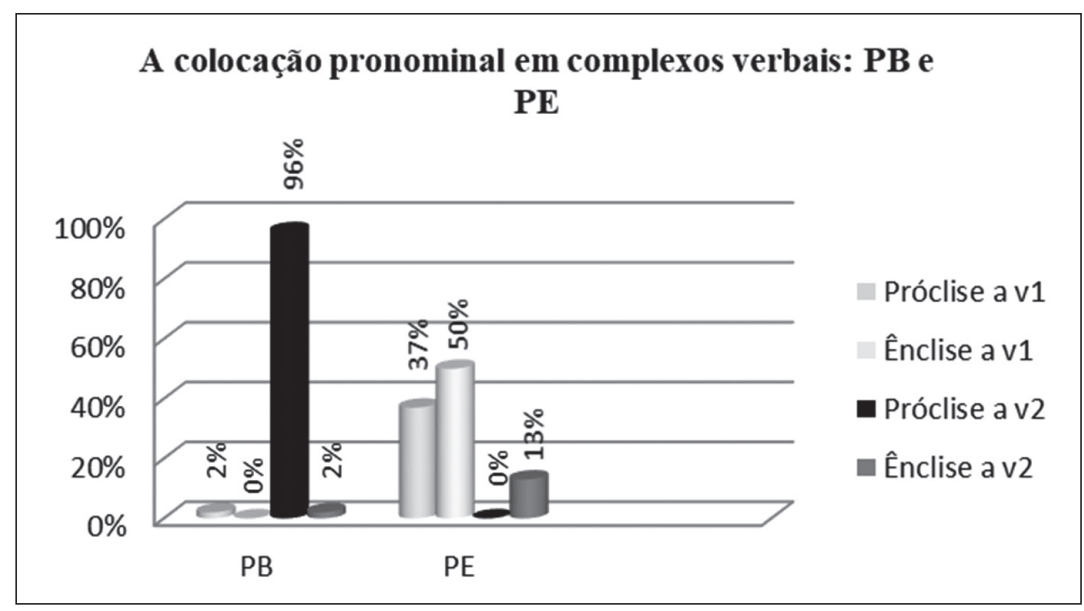

Figura 3 A ordem dos clíticos pronominais em complexos verbais do PB e do PE (variantes amalgamadas) segundo VIEIRA (2016)

Fonte: Vieira (2016: 176), adaptado

Como se pode observar, a regra de colocação nos complexos verbais do PB, assim como se atestou em construções com uma única forma verbal, não se apresenta efetivamente variável, mas semicategórica, registrando dados que podem ser interpretados como preferencialmente proclíticos a v2. A ligação sintática do clítico a v1 e a ênclise a v2 ficam condicionadas basicamente ao tipo de pronome. De outro lado, os dados de complexos verbais no PE apresentam colocação pronominal sensível às variáveis estruturais referentes ao contexto morfossintático em questão.

\section{A COLOCAÇÃO PRONOMINAL EM VARIEDADES URBANAS AFRICANAS: PST E PM}

Cumprindo o objetivo de apresentar descrições de variedades urbanas do Português, esta seção exibe resultados da ordem dos clíticos pronominais com base em amostras do Português falado em variedades africanas, quais sejam: a variedade de São Tomé (PST) e a de Maputo/Moçambique (PM). Trata-se de variedades em que igualmente o Português coexiste com várias outras línguas, embora mediante distintas realidades sociolinguísticas, conforme atesta Hagemeijer, no prefácio da presente obra: a moçambicana "está em contacto com línguas aglutinantes do grupo banto e apresenta uma taxa de nativização crescente, embora ainda relativamente baixa", enquanto a são-tomense "constitui a L1 da 
maioria da população, mesmo que os censos nacionais não explicitem esta informação"6.

\subsection{A colocação pronominal na variedade urbana de São Tomé}

Embora não se tenha por propósito, nos limites deste artigo, proceder a uma acurada revisão da literatura sobre o tema em cada variedade analisada, é notória a limitada produção bibliográfica sobre a ordem dos clíticos pronominais no PST $^{7}$. Esta seção baseia-se, portanto, conforme já anunciado, em resultados de análise do Corpus VAPOR também empreendida por Vieira (2016).

\subsubsection{Construções com uma só forma verbal}

Considerando as construções com uma única forma verbal, a Figura 4 permite observar a distribuição dos 525 dados em análise.

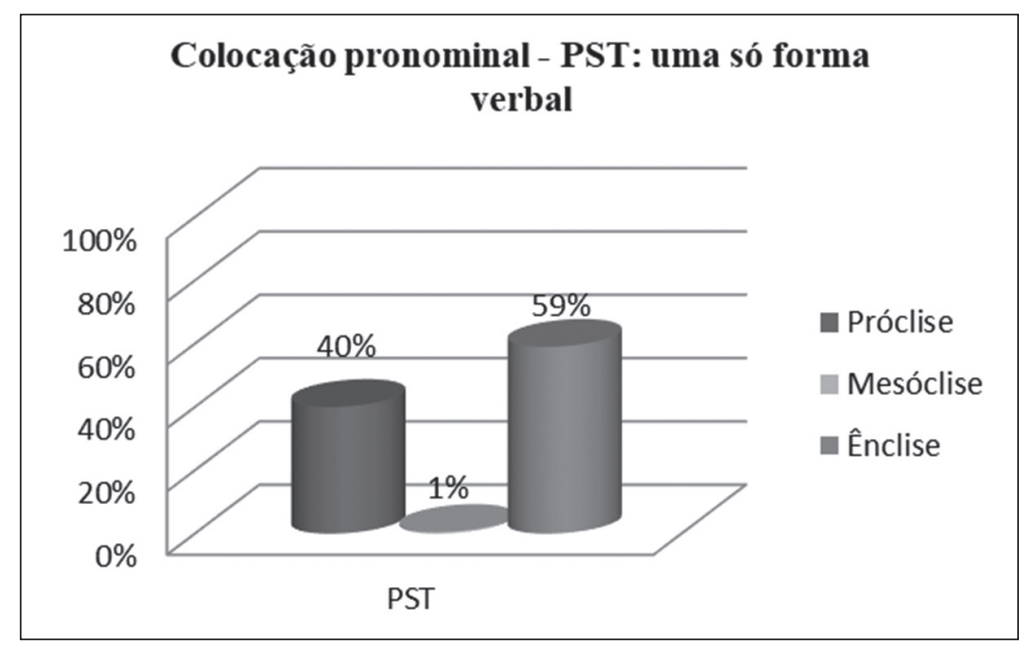

Figura 4 A ordem dos clíticos pronominais em complexos verbais na fala do PST segundo VIEIRA (2016)

Fonte: Vieira (2016: 121)

6 A respeito do multilinguismo em São Tomé e Príncipe, vale consultar Hagemeier (2009); quanto ao estatuto da variedade moçambicana do Português, também constitui leitura indispensável Gonçalves (2010).

7 Na revisão da literatura feita por Vieira (2016), faz-se alusão apenas à dissertação de Mestrado de Rita Gonçalves (2009), intitulada A Colocação dos Pronomes Clíticos no Português Oral de S. Tomé: Análise e discussão de contextos numa perspectiva comparativa, também desenvolvida com dados do Projeto VAPOR, já mencionado na introdução do presente texto. 
Como se pode observar, houve um número um pouco maior de dados de ênclise $(310 / 525 ; 59 \%)$ do que de próclise $(215 / 525 ; 40 \%)$ na amostra são-tomense. A distribuição dos dados alinha, portanto, o perfil dessa variedade mais ao do $\mathrm{PE}$ do que ao do $\mathrm{PB}$, no sentido de que o fenômeno se revela variável e não semicategórico, conforme se apresentou na seção anterior. Os exemplos 1 e 2 permitem verificar a referida variação:

Ex.1: fui trabalhar na casa de pessoa porque salário era muito baixo, também com a ajuda de minha avó sempre ela apoiou-me [PSTA1M $]^{8}$

Ex.2: eu tento lutar também porque a gente não pode sentar só esperar o que Deus vai dar né Deus, bíblia diz, Deus disse põe tua mão que eu te ajudo então eu ponho mão [PSTA1M]

Diferentemente de outras variedades controladas no estudo de Vieira (2016), encontrou-se uma ocorrência de mesóclise $(1 / 525 ; 1 \%)$ na amostra de São Tomé:

Ex.3: MAS é preciso que haja motivação por parte dos governantes e essa motivação tornar-se-ia mais extensiva aos professores [PSTC3H]

Em termos de comparação geral entre as variedades brasileira, europeia e são-tomense, Vieira afirma que:

O PST, de acordo com a análise, segue tendências gerais equivalentes às verificadas para o PE, quais sejam: (i) o fenômeno também se mostra variável; (ii) ocorre ênclise categórica em início absoluto de oração e de período (diferenciando-se ambas do PB radicalmente nesse contexto) e (iii) apresenta algumas variáveis linguísticas como condicionamentos favorecedores da próclise consoante as mesmas tendências gerais. (VIEIRA, 2016, p. 174)

Não obstante essa esperada semelhança geral entre as variedades europeia e são-tomense - visto ser a primeira, em tese, a norma de referência da segunda -, a autora, ao detalhar o comportamento dos dados quantitativa e qualitativamente, aponta importantes particularidades do PST.

Primeiramente, embora as variáveis linguísticas selecionadas - com exceção de Tonicidade da forma verbal - sejam as mesmas atuantes nos dados da amostra europeia no trabalho de Vieira (2016) - Elemento proclisador; Tempo/modo verbal; Distância entre o clítico e o termo antecedente -, a observação detalhada das

8 Para a identificação do perfil dos informantes, a notação que se faz ao fim de cada exemplo corresponde ao perfil quanto a variedade (PST = São Tomé; PM = Moçambique/Maputo); idade (A = 18 a 35 anos; $\mathrm{B}=36$ a 55 anos; $\mathrm{C}=$ de 56 anos em diante); escolaridade ( 1 - até 8 anos de escolaridade; 2 - cerca de 11 anos de escolaridade; 3 = curso superior completo); sexo ( $\mathrm{H}=$ homem; $\mathrm{M}=$ mulher). No caso da variedade moçambicana, identifica-se, ainda, a amostra em questão. 
variáveis e de cada contexto morfossintático particular permitiu aferir o comportamento típico do PST. Em segundo lugar, chama atenção a relevância estatística de variáveis extralinguísticas, quais sejam: Sexo, selecionada em primeiro lugar, e o grupo intitulado Frequência de uso de um crioulo, controlada segundo o depoimento dos próprios informantes.

O Quadro 2 apresenta, de forma resumida, os principais condicionamentos de cada variável linguística controlada.

Quadro 2 Sistematização da ordem dos clíticos pronominais em construções com uma só forma verbal no PST segundo VIEIRA (2016): variáveis linguísticas

\begin{tabular}{|l|l|l|}
\hline \multicolumn{1}{|c|}{$\begin{array}{c}\text { CONSTRUÇõES COM UMA } \\
\text { SÓ FORMA VERBAL }\end{array}$} & \multicolumn{1}{|c|}{$\begin{array}{c}\text { FATORES FAVORECEDORES } \\
\text { DA PRÓCLISE }\end{array}$} & $\begin{array}{l}\text { FATORES DESFAVORECEDORES } \\
\text { DA PRÓCLISE }\end{array}$ \\
\hline Elemento antecedente & $\begin{array}{l}\text { Partículas de negação } \\
\text { Elementos subordinativos } \\
\text { Preposições } \\
\text { Operadores de foco (com pouca } \\
\text { expressividade) }\end{array}$ & $\begin{array}{l}\text { Conjunções coordenativas } \\
\text { Sujeitos } \\
\text { Adjuntos adverbiais } \\
\text { Compl. preposicionados }\end{array}$ \\
\hline Tempo/modo verbal & Formas/tempos do subjuntivo & $\begin{array}{l}\text { Formas/tempos do indicativo } \\
\text { Infinitivo } \\
\text { Imperativo }\end{array}$ \\
\hline $\begin{array}{l}\text { Distância entre o clítico e o } \\
\text { elemento proclisador }\end{array}$ & $\begin{array}{l}\text { Ausência de elementos } \\
\text { intervenientes }\end{array}$ & $\begin{array}{l}\text { Presença de uma ou mais sílabas } \\
\text { intervenientes }\end{array}$ \\
\hline Tonicidade da forma verbal & Oxítonos & Paroxítonos e proparoxítonos \\
\hline
\end{tabular}

Fonte: Vieira (2016: 171-172), adaptado

A análise demonstra que o PST tende a utilizar, de modo geral, mais a variante enclítica do que a proclítica, sendo o início de oração contexto de realização categórica, assim como ocorre no PE. No que se refere aos elementos proclisadores, verifica-se que a atuação dos fatores também aproxima PE e PST: com exceção dos operadores de foco, que não se manifestaram como fator de próclise na amostra são-tomense de forma tão evidente, os elementos atuantes são basicamente os mesmos.

Observando, entretanto, os índices matemáticos providos pela análise estatística (consoante o pacote de programas Goldvarb-X), Vieira (2016) relata que a ação dos elementos proclisadores não revela "uma nítida dicotomia entre elementos proclisadores versus elementos não proclisadores, como ocorre no $\mathrm{PE}$ (com certa variação), mas há forte oscilação na colocação nos mesmos contex- 
tos sintáticos” (p. 217). Em outras palavras, as diferenças entre elementos favorecedores e desfavorecedores de próclise não seriam tão nítidas, exibindo distâncias menores. A autora declara que, no mesmo ambiente morfossintático, tanto a próclise como a ênclise são naturalmente concretizadas, como se pode verificar nos exemplos 4 a 9 :

Ex. 4: por exemplo, se formos para médico, eu já fui para para para para hospital hhh naquilo que chama-se de urgência [PSTA2H]

Ex. 5: posso apoiar também qualquer amigo qualquer amigo que me peça, vamos lá [PSTA1H]

Ex. 6: em termos de política (como que) oposição aí tinha problemas era mais no sentido/ ( ) não era porque o povo tava oprimido que não Se podia nada não falava-se... fazia-se tudo (normal) [PSTC2H]

Ex.7: A: Não, lá não, não se paga nada. hhh todo o mundo é bem-vindo [PSTA1H]

Ex. 8: dos dois um de química: e um de biologia ((risos)) Eu lembro-me é [PSTB3M]

Ex. 9: foi cubano... o de biologia no décimo primeiro também foi cubano... eu me lembro do/ dos dois professores que tive [PSTB3M]

Essa atuação menos rigorosa dos elementos proclisadores no PST em relação ao que ocorre no PE pode ser observada nas Figuras 5 e 6 :
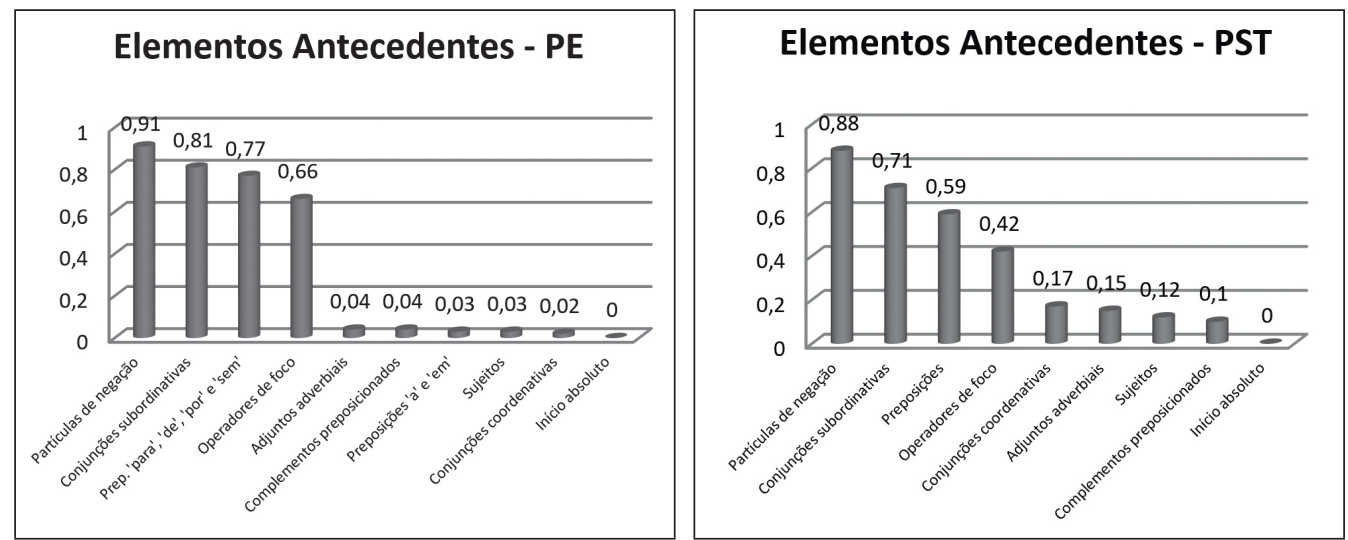

Figuras 5 e 6 Atuação da variável Elementos antecedentes no PE e no PST segundo Vieira (2016)

Fonte: Vieira (2016: 162)

Como se pode observar, enquanto o efeito proclisador nos dados do PE pode ser visualmente delimitado em dois grupos, ele ocorre no PST de forma mais gra- 
dual: a imagem deixa ver o decréscimo paulatino ${ }^{9}$ da atuação dos chamados fatores de próclise.

Além desse comportamento em certa medida instável, verifica-se, também, no PST a presença da variante pré-verbal diante de elementos que não atuam, até onde se sabe, como proclisadores no PE, como, por exemplo, conjunções coordenativas (exemplo 10) e SN sujeito (exemplo 11).

Ex. 10: lá naquelas tascas, não os altos restaurantes mas lá onde os pobres comem, viver e sentir o calor da cozinha, ver as panelas, enfim, cheias de tisna de de forno e de carvão mas me senti como se tivesse sido em casa [PSTA3H]

Ex. 11: Eu consegui conviver com a população, consegui mergulhar onde há pobreza em Nigéria, as pessoas me olhavam com bons olhos, consegui comer com os nigerianos [PSTA3H]

Exemplos como esses, considerados usualmente na literatura como inovações brasileiras - em que se verifica a próclise em contextos sem tradicionais proclisadores -, aliados a essa certa oscilação no comportamento quanto à ordem aproximam curiosamente certos dados do PST aos do PB. Gonçalves (2009), em estudo do tema com dados do PST, propõe que essa instabilidade é típica "de uma língua que ainda não está completamente formada, em especial em um contexto de plurilinguismo como o que existe em São Tomé", ou, ainda, "que, embora actualmente comece a afirmar-se como língua materna, foi adquirida como língua segunda" (GONÇALVES, 2009, p. 22). Por essa interpretação, a pesquisadora propõe que o Português em São Tomé "constitui uma interlíngua ainda não fossilizada pelo que a variação nas mesmas estruturas não nos permite caracterizar o sistema de colocação dos clíticos mas tão somente descrevê-lo o mais pormenorizadamente possível.” (GONÇALVES, 2009, p. 22).

Quanto às demais variáveis selecionadas, as tendências atestadas estão perfeitamente de acordo com as hipóteses formuladas: formas do subjuntivo, que ocorrem comumente na presença de elementos proclisadores, favorecem a variante pré-verbal, enquanto as demais a desfavorecem; elementos proclisadores atuam mais fortemente quando próximos ao verbo.

No que se refere especificamente à tonicidade das formas verbais, segundo o qual as formas oxítonas favorecem a próclise e as paroxítonas ou proparoxítonas a desfavorecem, Vieira associa esse resultado à hipótese de "a ligação fonológica do clítico no PST também ser para a esquerda, como supostamente ocorre com o

9 Vieira (2016) demonstra essa diferença entre as duas variedades pelo cálculo do range, medida que avalia as distâncias entre os índices relativos de cada fator. 
PE, formando, assim, vocábulos fonológicos com o que vem antes (ênclise fonológica) e não depois (próclise fonológica), como ocorre no PB.” (VIEIRA, 2016, p. 169). Nesse sentido, estaria reforçada a tendência à ênclise em geral, o que acaba por formar proparoxítonas (mandaram-me) e até esdrúxulas (ajudávamo-nos), como as registradas nos exemplos 12 e 13.

Ex. 12: porque o ministério conhece sabe que eu eu tenho uma segunda profissão que eu pratico de vez em quando eu acho que foi nessa base que mandaram-me pra aqui [PSTB3H]

Ex. 13: também naquela altura eu lembro-me do velho Costa Alegre o ( ) Aguiar e: muitos outros muitos outros (enfim) ajudávamo-nos muito no conhecimento da língua [PSTC3H]

Ainda que apontando a falta de dados e de evidências empíricas para qualquer conclusão de ordem rítmica e defendendo maior aprofundamento quanto a esse tipo de motivação, Vieira (2016) aventa a seguinte hipótese quanto aos resultados da variável Tonicidade da forma verbal:

Ademais, isso pode justificar o fato de não haver clíticos em início absoluto de oração e de período, pois a ligação fonológica do clítico no PST seria para a esquerda - como no PE -, ao contrário do PB, em que a ligação fonológica seria para a direita, como mostram os trabalhos de Vieira (2002) e Corrêa (2012). (VIEIRA, 2016, p. 169)

Quanto ao condicionamento extralinguístico, chama atenção a relevância estatística da variável Sexo do informante, cujos resultados se expõem na Tabela 2:

Tabela 2 A ordem dos clíticos pronominais de acordo com o Sexo do informante em construções com uma só forma verbal no PST segundo Vieira (2016)

\begin{tabular}{|l|c|c|c|}
\hline SEXO DO INFORMANTE & VALOR ABSOLUTO & PERCENTUAL & PESO RELATIVO \\
\hline Homem & $137 / 260$ & $53 \%$ & .57 \\
\hline Mulher & $78 / 265$ & $29 \%$ & .40 \\
\hline
\end{tabular}

Fonte: Vieira (2016: 155)

Os resultados demonstram que a fala indivíduos do sexo masculino favorece a variante proclítica (.57), em comparação à do sexo feminino (.40). Essa diferença de comportamento só pode ser seguramente interpretada com base em informações mais precisas com relação a aspectos tanto linguísticos quanto extralinguísticos.

Primeiramente, é preciso detalhar os contextos de utilização de próclise e de ênclise na subamostra de fala feminina e na masculina. A fim de detalhar esses 
contextos, Vieira (2016) procede ao cruzamento entre os grupos de fatores Sexo e Natureza do elemento antecedente. Consoante os resultados obtidos, foi possível verificar que a diferença mais expressiva de comportamento entre homens e mulheres está relacionada ao emprego de próclise ou ênclise diante dos elementos que não são tradicionalmente considerados proclisadores. Ao que parece, os homens, na busca de concretizar o efeito proclisador, acabam por generalizar a tendência e realizar mais a variante pré-verbal mesmo em contextos sem efetivos elementos proclisadores. Isso pôde ser verificado no caso das conjunções coordenativas $(\mathrm{H}-43 \% / \mathrm{M}-9 \%)$, adjuntos adverbiais $(\mathrm{H}-67 \% / \mathrm{M}-6 \%)$, sujeitos $(\mathrm{H}-25 \% / \mathrm{M}-14 \%)$ e complementos preposicionados $(\mathrm{H}-25 \% / \mathrm{M}-0 \%)$, diante dos quais os informantes do sexo masculino $(\mathrm{H})$ realizaram mais próclises do que as mulheres $(\mathrm{M})$.

Em termos sociais, entende-se ser fundamental interpretar os resultados da variável Sexo mediante o conhecimento relativo à inserção social de mulheres e homens na sociedade são-tomense, conhecimento de que não se dispõe efetivamente neste trabalho. A diferença verificada, segundo Vieira (2016, p. 156), "poderia estar vinculada ao fato de as mulheres, para se enquadrarem melhor na sociedade, utilizarem, ao máximo possível, as regras presentes na gramática do PE.”. Consoante essa hipótese, haveria relações distintas entre homens e mulheres em relação ao modelo europeu de colocação justificadas pela busca de prestígio no domínio da Língua Portuguesa. Certamente, a aferição dessa hipótese necessita de aprofundamento no conhecimento das relações na sociedade são-tomense.

Para o conhecimento da apropriação social da ordem dos clíticos na sociedade são-tomense, os resultados obtidos para a variável Frequência de uso de um crioulo podem ser esclarecedores. Essa variável investiga se os padrões de uso da colocação pronominal no PST estão relacionados à relação do usuário com o emprego, mais ou menos frequente, do Português ou da língua local, o Forro. Com base em Brandão (2011), os dados foram codificados de modo a controlar os seguintes fatores: (i) frequência zero ou baixa de uso do crioulo, quando os indivíduos declaram que se expressam fundamentalmente em Português; (ii) frequência média, quando os indivíduos declaram que se expressam em Português, mas dominam um crioulo e dele fazem uso eventualmente; e (iii) frequência alta, quando os indivíduos, embora falem o Português, declaram que se expressam, regularmente, num crioulo.

Os resultados obtidos não permitiram confirmar cabalmente a hipótese de que, quanto maior o uso do Português, maior o domínio da norma europeia de referência. Antes, sugerem que uma pessoa que usa frequentemente o crioulo seria a que mais produziria a variante proclítica $(0,89)$ - o que pode sinalizar uma tendência a generalizar a próclise por desconhecimento do efeito proclisador; em 
segundo lugar no que se refere ao uso da próclise, viriam os que supostamente não utilizariam o crioulo $(0,58)$ e, por último, os falantes que só o utilizam às vezes, mostrando que a próclise seria desfavorecida nesse caso $(0,39)$.

A análise desses resultados ainda não pode ser seguramente proposta em virtude dos limites metodológicos da pesquisa. Conforme propõe Vieira (2016),

efetivamente, qualquer interpretação das interinfluências do uso do Forro dependeria de pesquisa específica com amostra que controlasse efetivamente esse efeito, além de pesquisa etnográfica a respeito dos informantes e de sua relação com o uso da Língua Portuguesa e da língua local (p. 171).

De todo modo, a correlação entre esse grupo de fatores e a colocação pronominal mostrou-se relevante, o que permite traçar hipóteses para etapas futuras investigativas. Nesse sentido, Vieira (2016) observa:

Retirando o único informante que se declara como um falante do crioulo com alta frequência, verifica-se que os que afirmam utilizar basicamente o Português teriam uma preferência pela variante proclítica (possivelmente por dominar os contextos europeus de próclise), e os que conhecem e utilizam o Forro, mesmo que eventualmente, prefeririam a colocação enclítica, o que talvez possa sinalizar a influência da colocação pós-verbal dos pronomes objetos do crioulo, segundo Ferraz (1979) e Hagemeijer (2007). (VIEIRA, 2016, p. 170-171)

\subsubsection{Construções com mais de uma forma verbal}

A análise do tema no contexto de complexos verbais, que contou com um conjunto de 120 dados (cf. Tabela 3; Figura 7), mostra a produtividade das variantes, conforme a posição superficial e a presença ou não de material interveniente, na variedade são-tomense.

Tabela 3 A ordem dos clíticos pronominais nos complexos verbais do PST segundo Vieira (2016)

\begin{tabular}{|c|c|c|c|c|c|c|c|c|c|c|c|}
\hline \multicolumn{12}{|c|}{ A ORDEM DOS CLÍTICOS NOS COMPLEXOS VERBAIS PELA FORMA DE V2: PST } \\
\hline Variedade & \multicolumn{2}{|c|}{ cl v1 v2 } & \multicolumn{2}{|c|}{$v 1-c l x v 2$} & \multicolumn{2}{|c|}{ v1 (-)cl v2 } & \multicolumn{2}{|c|}{$\mathrm{v} 1 \mathrm{xcl}$ v2 } & \multicolumn{2}{|c|}{$\mathrm{v} 1 \mathrm{v} 2 \mathrm{cl}$} & Total \\
\hline PST & 26 & $22 \%$ & 12 & $10 \%$ & 45 & $38 \%$ & 14 & $12 \%$ & 23 & $18 \%$ & 120 \\
\hline
\end{tabular}

Fonte: Vieira (2016: 176)

A distribuição dos dados revela que, no PST, assim como no PE, ocorrem realizações de todas as variantes controladas, tendo sido a v1-cl v2 a mais produ- 
tiva $(38 \%)$, seguida pela próclise a v1 $(22 \%)$ e pela ênclise a v2 $(18 \%)$. Na presença de elemento interveniente $(\mathrm{x})$, ocorreram as colocações adjacentes a v1 (10\%) e a v2 (12\%). Nesse caso, é importante verificar o contexto em que as variantes se realizam, de modo a saber se ocorreria, por hipótese, a chamada próclise a v2, como no PB, ou se haveria apenas uma construção específica, como ocorre no PE, em que esse uso fica restrito a construções do tipo ter que/de mais infinitivo.

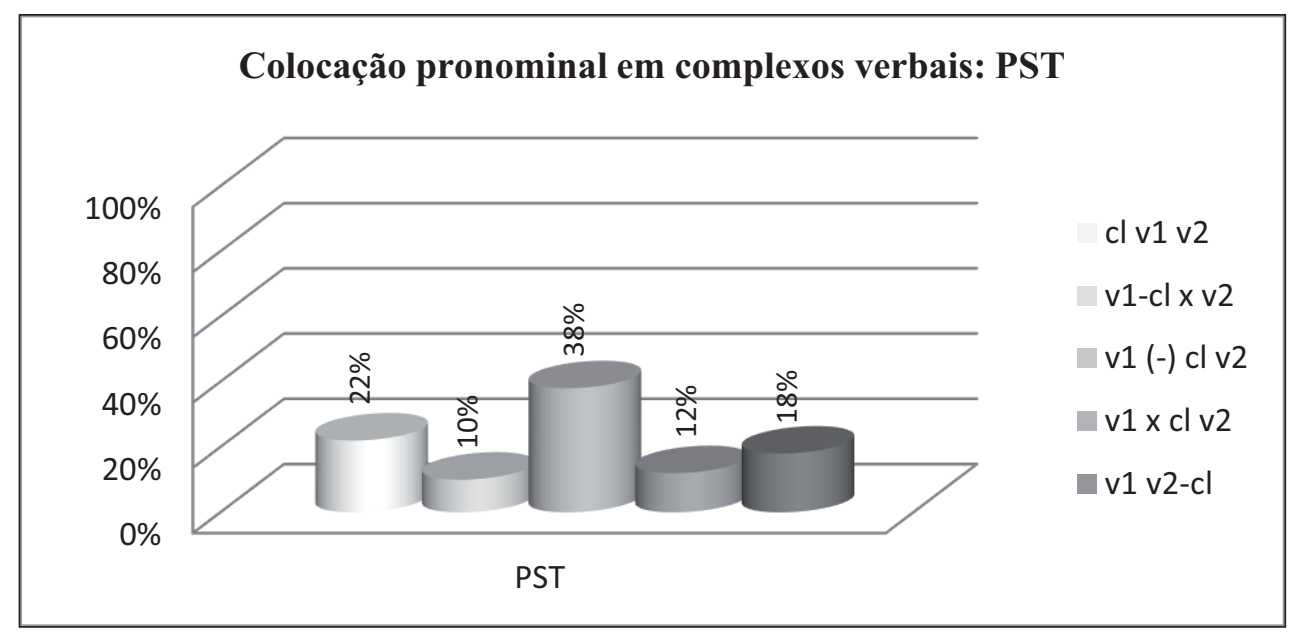

Figura 7 A ordem dos clíticos pronominais nos complexos verbais do PST segundo Vieira (2016)

Fonte: Vieira (2016: 176)

Primeiramente, é necessário observar que a maioria das ocorrências na amostra são-tomense é constituída de complexos com v2 infinitivo, tendo sido registrados apenas 11 dados de complexos com gerúndio e 5 com particípio, conforme se pode verificar na Tabela 4 .

Tabela 4 A ordem dos clíticos pronominais nos complexos verbais de acordo com a forma do verbo principal no PST segundo Vieira (2016)

\begin{tabular}{|l|c|c|c|c|c|c|c|c|c|c|c|c|}
\hline \multicolumn{10}{|c|}{ A ORDEM DOS CLITI OS NOS COMPLEXOS VERBAIS PELA FORMA DE V2: PST } \\
\hline V2 & \multicolumn{1}{|c|}{$c$ v1 v2 } & \multicolumn{1}{c|}{ v1-cl x v2 } & v1 (-) cl v2 & \multicolumn{2}{c|}{ v1 x cl v2 } & \multicolumn{2}{c|}{ v1 v2 cl } & \multicolumn{2}{|c|}{ Total } \\
\hline Infinitivo & 22 & $21 \%$ & 12 & $11 \%$ & 33 & $33 \%$ & 14 & $13 \%$ & 23 & $22 \%$ & 104 & $87 \%$ \\
\hline Gerúndio & 2 & $18 \%$ & 0 & $0 \%$ & 9 & $82 \%$ & 0 & $0 \%$ & 0 & $0 \%$ & 11 & $9 \%$ \\
\hline Particípio & 2 & $40 \%$ & 0 & $0 \%$ & 3 & $60 \%$ & 0 & $0 \%$ & 0 & $0 \%$ & 5 & $4 \%$ \\
\hline Total & 26 & $22 \%$ & 12 & $10 \%$ & 45 & $38 \%$ & 14 & $12 \%$ & 23 & $18 \%$ & 120 & $100 \%$ \\
\hline
\end{tabular}

Fonte: Vieira (2016, p. 203) 
Verifica-se que a opção preferencial no caso das construções com gerúndio e particípio é efetivamente a posição do clítico interna ao complexo, cuja ligação para v1 ou para v2 não se pode determinar a priori.

Ex. 14: uma vez que fazem aquilo que entendem não trabalham e se não trabalham não há produção e assim a pobreza vai se agravando portanto $[\mathrm{PSTB} 3 \mathrm{H}]$

Ex. 15: G: Exactamente, tem se feito algum esforço através da música [PSTA3H]

Tanto em complexos com gerúndio quanto em complexos com particípio, foram registradas, ainda, duas ocorrências de variante proclítica a v1 (como nos exemplos 16 e 17).

Ex. 16: nós temos que: tentar fazer de conta eh olhando um pouco também pra: pra transformações que se foram dando que se foram dando que é o caso perca de valores não é? [PSTB3M]

Ex. 17: a vida tem sempre altos e baixos momentos, bons e maus momentos, e falando sobre reportagem eu não estou a ver aqui muitas que me tenham marcado de forma chocante [PSTA3H]

Exemplos como esses - produzidos por indivíduos com curso superior - sugerem que o padrão de colocação pronominal são-tomense em complexos verbais seguiria as tendências do PE, de modo a efetivar o efeito proclisador também em construções com mais de uma forma verbal. Entretanto, a amostra, embora pequena, também apresentou dados (como nos exemplos 18, 19, 20) que contrariam essa tendência.

Ex. 18: eu acho que tem entrado muitos nigerianos e que não há controlo, eu não acredito que tem se feito uma avaliação [PSTB2M]

Ex. 19: É verdade que em tempos atrás, no período... no período, antes, né hhh, eu acho que já estou me perdendo um pouco [PSTA3H]

Ex. 20: a gente ouve um monte de besteira porque não estamos, não está a entender o que é que está se passando, cada um fala aquilo que ele imagina [PSTA1M]

Observar o conjunto de dados com complexos com v2 infinitivo (104 ocorrências) permitirá interpretar melhor a atuação das partículas proclisadoras nos dados de PST. Nessas construções, todas as variantes foram registradas.

Os 12 dados da ordem v1-cl x v2, com a presença de elementos intervenientes, constituem construções de natureza aspectual do tipo estar a + infinitivo, ir a + infinitivo, por a + infinitivo, habituar + infinitivo, começar a + infinitivo e, ainda, a estrutura modal ter que + infinitivo, todas elas combinadas com o pronome se, como nos exemplos 21 e 22. 
Ex. 21: o paludismo, o mosquito causador de paludismo quase que não se vê. Depois de terminar as pulverizações, dois, três, quatro meses começa-se a sentir novamente o ressurgir dos mosquitos [PSTA3M]

Ex. 22: A: nem por isso. Nem por isso. Está-se a complicar cada dia [PSTA3M]

Dos 14 dados com a variante $\mathrm{v} 1 \mathrm{x} \mathrm{cl}$ v2, dez são do tipo ter que + infinitivo, conforme se atestou nos dados do PE. Chamam a atenção, entretanto, 4 ocorrências que não são desse tipo, apresentadas a seguir.

Ex. 23: não sei o que é que estava por detrás das coisas mas, infelizmente, essas pessoas lá não estavam a se revelar muito simpáticas [PSTA3H]

Ex. 24: não é que eu não tenha mais para dar, mas eu acho que eu dei o meu contributo, eu dei o meu contributo, eu estou a me licenciar agora para poder aplicar [PSTA3H]

Ex. 25: depois estava a dar entrevista ontem a dizer não sei quê não sei quê que é culpa de não sei quê. É culpa de quem? Ele é que é culpado. O indivíduo pode até se exprimir assim, abertamente [PSTA3H]

Ex. 26: Os mais velhos, esses infelizmente estão a morrer, né, eles que têm mais conhecimento disso, estão a morrer e não estão a... os jovens hoje em dia não estão a se interessar que é para aprender essa língua [PSTA3M]

Ao que tudo indica, a tendência mais geral do PST é a de registrar a ênclise a V1, assim como se verificou no PE. Os exemplos ora, em análise, trazem, no entanto, uma reflexão adicional acerca da oscilação de comportamento dos dados do PST. Os exemplos que contêm a preposição $a$ interveniente particularizam o comportamento da variedade são-tomense em relação à europeia. Segundo Gonçalves (2010, p. 52-53), procedendo à listagem das características diferentes do Português em Moçambique, essas estruturas seriam traços distintivos de PM e PE, visto que seria típico da variedade europeia a posição do clítico após v2 (estavam a revelar-se; estou a licenciar-me; estão a interessar-se). No exemplo 25 , em especial, chama atenção a adjacência do pronome a v2 após o elemento interveniente até. Essa construção costuma ser apontada, costumeiramente, como a inovadora próclise a v2, registrada no $\mathrm{PB}$.

Conforme destaca Vieira (2016),

(...) é digno de nota o registro dessa ocorrência na amostra são-tomense, em termos qualitativos, mesmo sendo apenas um dado. Em última análise, essa ocorrência pode sugerir que os informantes são-tomenses admitam, ainda que raramente, o pronome proclítico a v2, a variante considerada uma inovação brasileira, sendo, assim, uma particularidade do PST, não verificada 
na amostra do presente trabalho em relação ao PE (nem em trabalhos anteriores como os de Vieira (2002) e Vieira, M. F. (2011)). Caso realmente se confirme ser esse dado natural no PST, aumenta a confiabilidade da hipótese de que a instabilidade advinda da situação de multilinguismo que envolve a implementação da Língua Portuguesa em São Tomé, por causa da intensa situação de contato linguístico, possa explicar as feições diferenciadas de uma língua transplantada em relação à língua do colonizador, como também aconteceu no caso do PB. (VIEIRA, 2016, p. 204-205)

No que se refere à posição do clítico antes do complexo verbal, em 22 dados com o infinitivo, cabe registrar que ela sempre ocorreu após a presença de elemento proclisador. No entanto, assim como no PE, o efeito proclisador não se deu de forma categórica, de modo que, mesmo estando o clítico antecedido de elementos subordinativos, partículas de negação e operadores de foco, foram registradas as variantes enclítica a v1 ou a v2, como se pode verificar nos exemplos 27 a 29.

Ex. 27: Eu se estiver a precisar de dois mil dólares para, pronto, só um exemplo, para editar um disco, o mínimo que possam me dar [PSTA3H]

Ex. 28: A: Eles não vão me perseguir porque eu não tenho dinheiro. [PSTB1M]

Ex. 29: sinta bem é na minha casa origem... é: eu fico fico mesmo antes que venha me fazer mais confusão a cabeça [PSTB3M]

A colocação depois do complexo verbal (como nos exemplos 30 e 31), em 23 dados com o infinitivo, ocorreu com diversos tipos de complexos verbais e pronomes ( $m e, s e, o(s)$ e lhe), em estruturas com elementos proclisadores ou não, como ocorreu no PE.

Ex. 30: eu julgo que... para pessoa... do do meu cariz, a pessoa do meu próprio tipo, eu acho que devo voltar-me mais para a sociedade [PS$\mathrm{TA} 3 \mathrm{H}]$

Ex. 31: se não te: $\mathrm{m}$ é claro que não / (ela) não pode manifestar-se né? [PSTB3M]

Em todos os tipos de complexos, foram encontrados dados em que há um elemento proclisador e que não ocorre a variante anterior a v1. Dados desse tipo confirmam o que se estabelece em Martins (2013) para o PE: no caso de complexos verbais, o pronome átono pode ocorrer, quando há um elemento proclisador, não só antes do complexo, mas também depois dele. No PST, essa variação parece ser ainda mais intensa, visto que a oscilação do efeito proclisador, que foi verificada nas estruturas com uma só forma verbal, pode ter sido intensificada nos complexos verbais. Ademais, chama a atenção, ainda que em poucos dados, o 
registro de clíticos em posições até então não verificadas no PE, como a suposta próclise a v2.

De modo geral, constata-se que, enquanto não se verifica na amostra referente ao PB efetiva variação e a regra é do tipo semicategórico (LABOV, 2003), dado seu perfil quantitativo e qualitativo, o comportamento dos dados do PE e do PST se correlaciona ao de uma regra variável, com comportamentos particulares a depender da forma de v2.

\subsection{A colocação pronominal na variedade urbana de Moçambique}

Reportam-se, nesta seção, resultados de investigações com entrevistas sociolinguísticas realizadas em Maputo, capital do país, recortando-se, para o presente artigo, exclusivamente os resultados referentes às construções com uma só forma verba $1^{10}$. Apresentam-se, primeiramente, os resultados da tese de Doutorado de Vieira (2002) - que observou o fenômeno no Corpus PPOM, com entrevistas realizadas nos anos de 1990 - e, em seguida, as tendências gerais verificadas em uma amostra reduzida (com apenas seis entrevistas) do Corpus Moçambique, constituído em 2016.

Vieira (2002) analisa, do conjunto de entrevistas do Corpus PPOM, 1347 ocorrências da ordem dos clíticos pronominais na fala de 38 entrevistados, distribuídos, quanto à faixa etária, em três grupos - faixa A (18 a 35 anos), faixa B (36 a 55 anos), faixa C (56 anos em diante). Dadas as particularidades no processo de aprendizagem do Português, a autora respeitou os níveis de escolaridade propostos pelos organizadores do referido corpus: nível $1-$ da $3^{a}$ a $7^{a}$ classe -; nível 2 da $8^{a}$ a $11^{2}$ classe; nível 3 - frequência universitária. Na medida do possível, foram utilizadas cinco entrevistas por faixa etária e nível escolaridade. ${ }^{11}$

A distribuição das 1347 ocorrências pelas variantes pré e pós-verbal ocorreu conforme se detalha na Figura 8.

10 Não se apresentam os resultados para os complexos verbais considerando o Corpus Moçambique, primeiramente porque a análise da ordem dos clíticos nessas construções ainda não foi concluída. Ademais, os resultados apresentados por Vieira (2002), com base na análise de dados do Corpus PPOM, foram adquiridos com base em metodologia - a partir de regra binária de colocação - diferente da adotada por Vieira (2016) - a partir de regra eneária - para o PST, o que não facilitaria a comparação dos resultados no presente artigo.

11 Não foi possível, no estudo de Vieira (2002), valer-se de cinco entrevistas por faixa etária no caso do grau de instrução máximo (frequência universitária), o que se justifica pelas limitações do próprio Corpus PPOM, que não dispunha de mais inquéritos do referido perfil além dos utilizados. Também não foi possível selecionar os informantes segundo a variável Sexo do informante, visto que os inquéritos não foram distribuídos uniformemente entre homens e mulheres. 


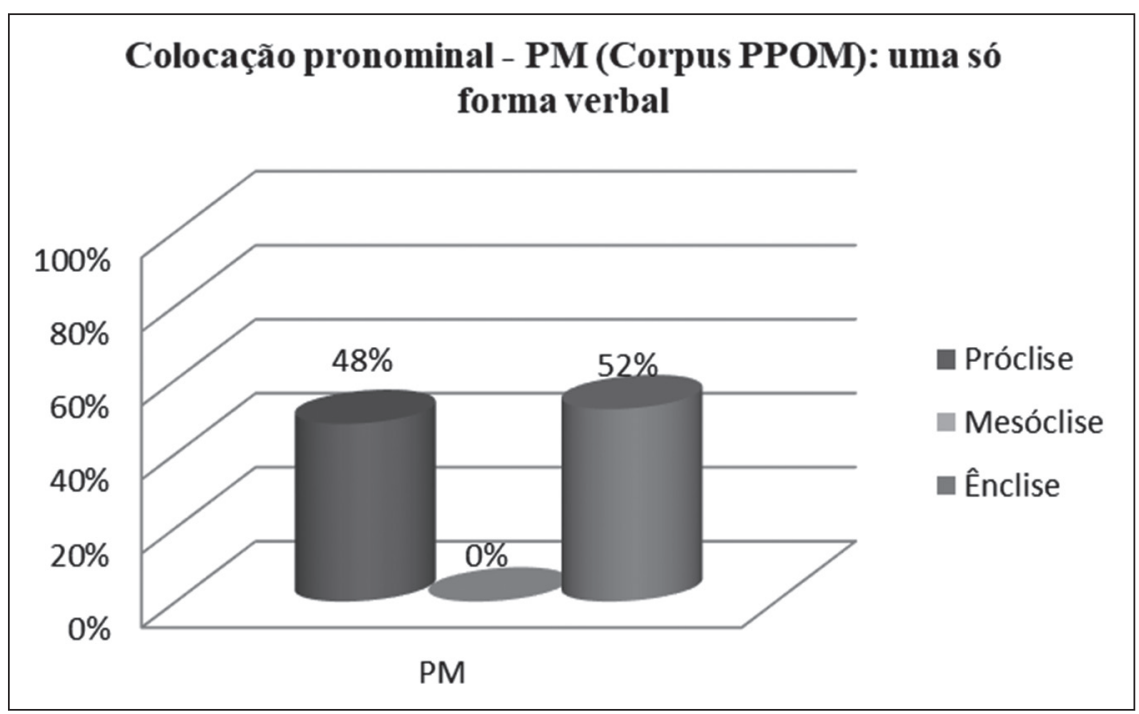

Figura 8 A ordem dos clíticos em construções com uma só forma verbal na fala do PM segundo Vieira (2002) - Corpus PPOM

Fonte: Vieira (2002: 85)

De modo geral, a distribuição das ocorrências também remete à esperada semelhança entre as variedades europeia e moçambicana. Entretanto, ao detalhar o comportamento dos dados quantitativa e qualitativamente, Vieira (2002) detecta particularidades do PM. Segundo a autora, a tendência do PM à variante pós-verbal é expressiva, ocorrendo, inclusive, em contextos em que se espera a anteposição do pronome ao verbo. Em outras palavras, a variedade moçambicana tende a realizar a ênclise de forma generalizada.

Esse comportamento geral foi atestado por pesquisadores (GONÇALVES; MORENO; TUZINE; DINIZ; MENDONÇA, 1998) que realizaram um primeiro diagnóstico das principais especificidades do Português Oral de Maputo, incluindo os produzidos no âmbito do Corpus PPOM. Considerando as estruturas gramaticais do Português que demonstram as áreas de dificuldades de aprendizes moçambicanos, os referidos autores declararam:

No que diz respeito aos padrões da ordem dos pronomes átonos, registam-se com maior frequência casos de adopção do padrão enclítico (V-Pron) (ver também Nhampule (1996) e Gonçalves (1997)), mesmo quando se trata de contextos que, de acordo com a norma europeia, exigem a próclise. (p. 62)

A fim de demonstrar os condicionamentos da próclise na variedade moçambicana, Vieira (2002) detalha o comportamento das variáveis que se mostraram 
sistematicamente relevantes ${ }^{12}$ ao condicionamento da ordem dos clíticos no Corpus PPOM, quais sejam: a presença de operador de próclise na oração e a distância entre o operador de próclise e o grupo clítico-verbo. Com o controle detalhado dos fatores da primeira variável, a análise empreendida pela autora forneceu os resultados detalhados na Tabela 5 .

Tabela 5 Aplicação da próclise de acordo com a variável Presença de operador de próclise em construções com uma só forma verbal no PM segundo Vieira (2002) - Corpus PPOM

\begin{tabular}{|l|c|c|c|}
\hline \multicolumn{1}{|c|}{ OPERADOR DE PRÓCLISE } & VALOR ABSOLUTO & PERCENTUAL & PESO RELATIVO \\
\hline Nenhum & $8 / 285$ & $3 \%$ & .06 \\
\hline SN sujeito nominal & $10 / 57$ & $18 \%$ & .38 \\
\hline SN sujeito pronomes & $7 / 56$ & $13 \%$ & .30 \\
\hline Conjunçães coordenativas & $12 / 125$ & $10 \%$ & .17 \\
\hline SAdv - aqui, ali, cá, lá, já & $16 / 28$ & $57 \%$ & .61 \\
\hline SAdv - sempre, talvez.. & $9 / 31$ & $29 \%$ & .36 \\
\hline SAdv - -mente e loc.adv. & $1 / 15$ & $7 \%$ & .22 \\
\hline Elemento "denotativo" & $6 / 20$ & $30 \%$ & .34 \\
\hline Preposição a, em & $3 / 20$ & $15 \%$ & .36 \\
\hline Preposição para, de, sem & $113 / 138$ & $82 \%$ & .66 \\
\hline Partícula de negação & $177 / 179$ & $99 \%$ & .99 \\
\hline Conj. subordinativa e int. se & $56 / 79$ & $71 \%$ & .60 \\
\hline Conjunção integrante que & $25 / 52$ & $48 \%$ & .29 \\
\hline Elemento que - outros & $182 / 229$ & $79 \%$ & .73 \\
\hline Pron./adv. relativo + pal. QU- & $26 / 32$ & $81 \%$ & .74 \\
\hline
\end{tabular}

Fonte: Vieira (2002: 191)

De acordo com os resultados, constituem elementos favorecedores da variante pré-verbal: a partícula de negação, os pronomes/advérbios relativos e palavra

12 Vieira (2002) demonstra que atuaram também, em segundo plano, o tipo de oração e o tipo de clítico, variáveis que não puderam ser apresentadas considerando os propósitos e os limites do presente artigo. 
QU-, o elemento que (excetuando-se a conjunção integrante), as preposições (exceto $a$ e $e m$ ), o SAdv do tipo aqui e a conjunção subordinativa/integrante se. Não favorecem a próclise os seguintes fatores: ausência de operador, conjunção coordenativa, SAdv do tipo sempre, SAdv em -mentel locução adverbial, SN sujeito nominal, elemento chamado denotativo (operador de foco), preposições a e em e conjunção integrante que. Levando em consideração todos os contextos possíveis reunidos ao máximo por semelhança, Vieira (2002) apresenta os resultados reunidos em quatro fatores, conforme se expõe na Tabela 6.

Tabela 6 Aplicação da próclise de acordo com a Presença de operador de próclise na oração (variantes amalgamadas) em construções com uma só forma verbal no PM segundo Vieira (2002)

\begin{tabular}{|l|c|c|c|}
\hline \multicolumn{1}{|c|}{ OPERADOR DE PRÓCLISE } & VALOR ABSOLUTO & PERCENTUAL & PESO RELATIVO \\
\hline Nenhum & $8 / 285$ & $3 \%$ & .06 \\
\hline SN sujeito & $17 / 113$ & $15 \%$ & .30 \\
\hline Conj. coordenativa/ Exp. adverbiais & $38 / 199$ & $19 \%$ & .27 \\
\hline Operadores diversos & $588 / 749$ & $79 \%$ & .81 \\
\hline
\end{tabular}

Fonte: Vieira (2002: 192)

Não constituem, de um lado, contextos favorecedores da próclise a ausência de um operador (.06), o SN sujeito (.30), a conjunção coordenativa e as expressões adverbiais (.27); de outro lado, figuram os demais operadores, que favorecem a variante pré-verbal (.81).

O efeito da distância entre o operador de próclise e o grupo clítico-verbo também se confirmou, como se pode observar nos resultados expostos na Tabela 7.

Tabela 7 Aplicação da próclise de acordo com a Distância entre o elemento proclisador e o verbo na oração em construções com uma só forma verbal no PM segundo Vieira (2002) - Corpus PPOM

\begin{tabular}{|l|c|c|c|}
\hline \multicolumn{1}{|c|}{ DISTÂNCIA ENTRE O OPERADOR E CL-V } & VALOR ABSOLUTO & PERCENTUAL & PESO RELATIVO \\
\hline Zero sílaba & $542 / 726$ & $75 \%$ & .56 \\
\hline Uma a cinco sílabas & $66 / 156$ & $42 \%$ & .33 \\
\hline Seis a dez sílabas & $8 / 34$ & $24 \%$ & .13 \\
\hline Onze sílabas em diante & $9 / 18$ & $50 \%$ & .43 \\
\hline
\end{tabular}

Fonte: Vieira (2002: 193) 
A codificação dessa variável evidencia que, no PM, a distância atenua, até certo ponto, o efeito da operação de próclise. Essa afirmativa baseia-se na redução gradativa dos índices de próclise do contexto zero sílaba até seis a dez sílabas $(.56>.33>.13)$. O último fator - onze sílabas em diante - apresenta índice de próclise (.43) semelhante ao da média geral (.49) do corpus. Parece que, estando o operador muito distante do clítico, o efeito da chamada atração deixa de existir, de modo que os dados se comportam conforme a tendência geral da variedade moçambicana.

Embora se tenha atestado a relevância dos grupos de fatores presença de operador de próclise na oração e distância entre o operador e o grupo clítico-verbo, o condicionamento dessas variáveis no PM é menos sistemático do que o verificado no PE: o comportamento dos fatores evidencia a já referida instabilidade da chamada operação de próclise. Tanto a seleção desses grupos quanto o fato de com eles ora interagirem outras variáveis de natureza morfossintática - como tipo de oração, tempo e modo verbais e tipo de clítico - revelam essa assistematicidade. A esse respeito, a observação de exemplos reafirma o verificado.

Ainda que não sejam de alta produtividade, chamam a atenção ocorrências de clíticos nos seguintes contextos:

* em início de oração

Ex. 32. ((pergunta do doc.)) me é difícil porque o meu pai ainda não arranjou nenhuma madrasta de lá ate cá (PMA2-PPOM, PC1URA)

* com SN sujeito nominal:

Ex. 33: os rapazes e as raparigas se preparam se conhecem se conhecem para que futuramente consigam viver em conjunto (PMA3-PPOM, inf. PC9GRI)

Ex. 34: quando eu nasci comecei a: na machamba a minha avó me obrigava muito para andar na machamba (PMC1-PPOM, inf. MX16LIN) * com SN sujeito pronominal:

Ex. 35: dezassete horas tinha que estar em casa... trancada... não podia brincar com ninguém... eu me sentia muito mal porque eu gostava de brincar (PMA2-PPOM, inf. PC1URA)

Ex. 36: partindo mesmo do namoro... ainda novos e: enquanto existe esse abuso.. essa falta de respeito em casa... eles se precipitam... "ah vamos casar" porque tem tem dinheiro tem condições "vamos casar" casam-se (PM-A1-PPOM, inf. MF13SUR)

* após conjunções coordenativas e/ou advérbios em -mente: 
Ex. 37: tem praticamente essa janela fechada e praticamente se torna ignorante - e a ignorância - é um mal extremamente grande (PM-A3PPOM, inf. PC9GRI)

Ex. 38: mulheres mas se diz homens engenheiros e mulheres (PM-A3PPOM, inf. PC19CUN)

Como se pode observar, mesmo na ausência de elementos proclisadores, foi registrada a variante proclítica, comportamento não aferido nas amostras do PE que foram estudadas até o momento.

De outro lado, diversas ocorrências de ênclise ocorreram em contextos com a presença de operadores de próclise. Segundo Vieira (2002), "na variedade oral moçambicana, o desrespeito à tradicional "atração" alcança um número considerável de dados, especialmente no caso da conjunção integrante $<q u e>$, que chega a registrar mais ênclise do que próclise (48\%)" (VIEIRA, 2002, p. 111). A autora oferece diversos exemplos para comprovar essa tendência.

Ex. 39: a falta de respeito posso não posso dizer que deve-se ao professor porque muitas das vezes até os alunos faltam respeito ao professor (PM-A3-inf. AM23VRA) [conjunção integrante que]

Ex. 40: os médicos diziam que eu sentia-me fraca - cansaço (PMA1-PPOM, inf. MX3MAR) [conjunção integrante que]

Ex. 41: agora eu não sei a: a razão principal se de facto deve-se à falta de namoro (PMA2-PPOM, inf. PC6GRA) [conjunção integrante se]

Ex. 42: sempre a do noivo é de dizer $<<$ não tenho dinheiro porque todo o dinheiro gastei no lobolo >> e que só depois de muito tempo ou chega-se a não... a não realizar-se o casamento - porque ele sempre vai-se desculpar porque não tem dinheiro (PMA2-PPOM, inf. CH12ODJ) [partícula de negação]

Ex. 43: não posso contar assim muito... sei lá... porque sempre quando desloco-me a Nampula o meu pai tem ido lá em missão de serviço (PMA2-PPOM, inf. CH12ODJ) [conjunção subordinativa]

Ex. 44: a igreja é muito importante - muito importante eu acho porque: nasci e cresci na igreja até agora - embora diz-se - né? haver certas igrejas que existe só para explorar ou apoderar-se do dinheiro de alguns (PMA1-PPOM, inf. MX2SIM) [conjunção subordinativa]

Ex. 45: acho que não tem possibilidade para tal: mas se alguém abre-se - amostra a simpatia dele - que é a educação dos próprios pais deve-te cumprimentar (PMA1-PPOM, inf. MX3MAR) [conjunção subordinativa] 
Ex. 46: depende da sorte que elas tiverem né? do marido ou namorado que apareceu-lhes em frente (PM-A2-PPOM, inf. CH12ODJ) [pronome relativo que]

Ex. 47: isso não sei dizer porque os meus pais é que disseram-me (PMB1-PPOM, inf. MF1ANA) [estrutura clivada]

Ex. 48: a minha infância direi que uma parte não foi feliz a outra foi não foi feliz porque eu era muito mimado com os pais - não deixavam-me sair tanto de casa - como/ quem batia-me fora sempre eles iam lá defendiam-me (PMA3-PPOM, inf. PC2CEL) [pronome relativo quem]

Ex. 49: porque tínhamos que dormir no mato tinha mesmo sítio próprio onde a gente tinha que dormir onde chamava-se de placa eram sítios que - basta anoitecer tínhamos todos que correrem (PMB1-PPOM, inf. MF1ANA) [advérbio relativo onde]

Com base nos índices quantitativos e na análise qualitativa das ocorrências, a autora chega a concluir sua apreciação da seguinte forma:

Ao que parece, esse número expressivo de casos em que o possível operador de próclise não "opera" revela um traço caracterizador da variedade moçambicana e não uma espécie de "deslize" em relação ao que seria "normal" ocorrer. (VIEIRA, 2002, p. 111)

A esse respeito, Gonçalves (2010) generaliza e confirma o que se registrou anteriormente em Gonçalves; Stroud (1998), mencionando ser a colocação pronominal fenômeno sintático que distingue PM e PE.

Quanto aos fenômenos mais estritamente sintácticos que distinguem o PM do PE, e no que diz respeito aos padrões de ordem dos pronomes pessoais átonos, salienta-se em primeiro lugar a tendência para adoptar a ênclise em contextos em que estão presentes <<atratores> de próclise, sobressaindo, pela sua frequência, os casos em que está presente um complementador. (GONÇALVES, 2010, p. 52)

A fim de observar se as tendências ora descritas no Corpus PPOM se verificam em outros materiais, apresentam-se, a seguir, resultados preliminares da análise das entrevistas do Corpus Moçambique ${ }^{13}$. Leva-se, aqui, em consideração

13 Está em curso a análise dos 18 informantes da amostra de entrevistas sociolinguísticas no âmbito do Projeto Estudo comparado dos padrões de concordância em variedades africanas, brasileiras e europeias do Português. Os resultados dessa análise permitirão maior detalhamento não só das construções com uma só forma verbal, mas também com os complexos verbais. 
a fala de apenas seis entrevistas sociolinguísticas produzidas em 2016, referentes a informantes jovens (de 18 a 35 anos de idade), distribuídos por sexo e escolaridade, sendo dois de cada nível - fundamental, médio e superior.

No referido conjunto de entrevistas, foram coletados 153 clíticos em construções com uma única forma verbal, com a distribuição pelas variantes controladas conforme representada na Figura 9.

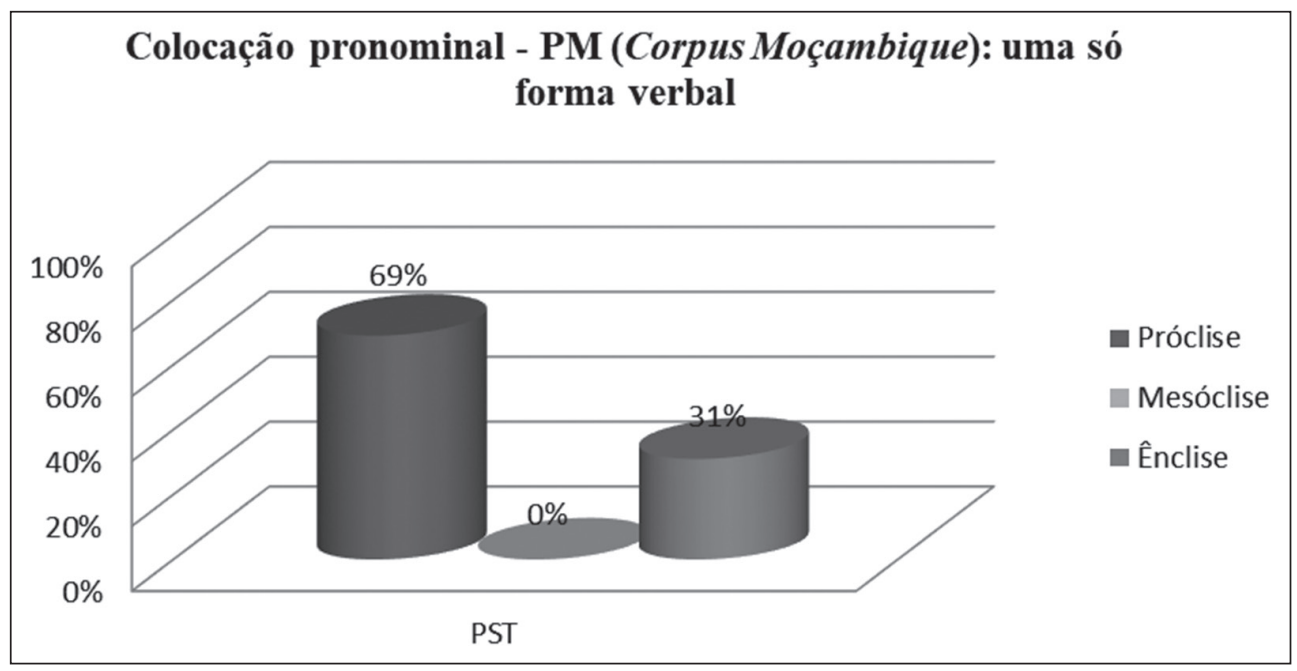

Figura 9 A ordem dos clíticos em construções com uma só forma verbal na fala do PM - Corpus Moçambique

Comparando esses resultados gerais aos obtidos por Vieira (2002), verifica-se, em termos absolutos, índice menor do uso dos pronomes oblíquos na posição pós-verbal. Os índices revelaram alta produtividade da próclise na amostra observada, que chega a $69,3 \%$ dos dados coletados na fala dos seis informantes.

$\mathrm{Da}$ análise variacionista, foram consideradas relevantes para o condicionamento da próclise as variáveis Escolaridade, Sexo, Lingua 1 do informante e Presença de elemento proclisador.

Em termos linguísticos, embora os presentes resultados sejam preliminares, eles confirmam a particularidade nos padrões de colocação pronominal da variedade moçambicana. Em alguns contextos, ao que tudo indica, o PM segue as tendências conhecidas na variedade europeia (como o efeito proclisador ou não proclisador, de modo geral); em outros, chama atenção o registro de ocorrências que não costumam ser observadas no PE, mas são comumente encontradas na variedade brasileira. A Tabela 8 apresenta os resultados obtidos para a variante pré-verbal em cada contexto controlado. 
Tabela 8 Aplicação da próclise em construções com uma só forma verbal de acordo com a variável Efeito proclisador no PM - Corpus Moçambique

\begin{tabular}{|l|c|c|c|}
\hline \multicolumn{1}{|c|}{ EFEITO PROCLISADOR } & V. ABSOLUTO & PERCENTUAL & PESO RELATIVO \\
\hline Início absoluto & $3 / 20$ & $15 \%$ & .06 \\
\hline Sujeito SN & $8 / 17$ & $47.1 \%$ & .10 \\
\hline Sujeito - Pronome & $17 / 18$ & $94.4 \%$ & .73 \\
\hline Advérbio & $6 / 11$ & $54.5 \%$ & .29 \\
\hline Locução adverbial e advérbio em -mente & $0 / 5$ & $0 \%$ & - \\
\hline Conjunção coordenativa & $7 / 10$ & $70.0 \%$ & .29 \\
\hline Preposição & $14 / 15$ & $93.3 \%$ & .78 \\
\hline Elemento subordinativo & $30 / 32$ & $93.8 \%$ & .83 \\
\hline
\end{tabular}

Em primeiro lugar, chama atenção a presença de próclise em quase todos os contextos controlados (exceto após locução adverbialladvérbio em -mente, contexto com apenas cinco dados, todos em ênclise), inclusive em início de oração, embora este tenha se mostrado como contexto altamente favorecedor da variante pós-verbal, como se atesta nos exemplos 50 e 51.

Ex. 50: é muito comum música angolana ouvir música angolana cá... mas também já vai crescendo o número de música moçambicana... ouve-se pouco é verdade...também devido à falta de... de qualidade... mas já: há coisas de qualidade... na praça (PMA3H-Corpus Moçambique)

Ex. 51: imagine por exemplo num casamento... são dois normalmente na cultura ocidental... eh o eh eh eh... vai-se à igreja ou ou ou registo né... casam... (PMA3H-Corpus Moçambique)

Quanto aos demais contextos, é possível delimitar o conjunto dos elementos que favorecem a próclise e os que não a favorecem. Pertencem ao primeiro grupo os seguintes fatores: elemento subordinativo, sujeito na forma pronominal e preposição. Pertencem ao grupo de elementos desfavorecedores da próclise os seguintes fatores: início absoluto, sujeito na forma nominal, advérbio, locução adverbialladvérbio em-mente e conjunção coordenativa.

Há que se destacar o número expressivo de dados de próclise em contextos diferentes dos verificados para a variedade europeia. A esse respeito, observam-se, particularmente, os dados em que os clíticos são antecedidos de pronomes na função de sujeito, os quais registraram $94.4 \%$ de próclise (.73), tendo sido produzidos por indivíduos de diferentes níveis de escolaridade. 
Ex. 52: eu encontrei um senhor/ isso qual foi em dois mil e onze senhor falou para mim disse assim "peço ajuda" era no domingo eu "ajuda sim" "trago aqui pedras preciosas" "eu preciso de chegar no câmbio" ele me amostrou (PMA1H-Corpus Moçambique)

Ex. 53: e: educação saúde quer dizer com o nível de vida que levamos que não é bom hhh nós nos forçamos muito (PMA3M-Corpus Moçambique)

Quanto aos demais contextos favorecedores da próclise (preposição e elementos subordinativos), os resultados apenas confirmam o verificado em amostras da variedade europeia da Língua Portuguesa. No que diz respeito à preposição, o PM realizou a próclise segundo uma taxa de 93.3\% (.78); o elemento subordinativo também apresentou preferência pela variante pré-verbal, com taxa de $93.8 \%$ (.83), confirmando a tendência à variante pré-verbal, embora também não seja de forma categórica.

Em termos extralinguísticos, o estudo preliminar da fala dos informantes mais jovens do Corpus Moçambique sugere que a preferência pela próclise parece estar correlacionada à fala das mulheres, ao aprendizado do Português como segunda língua e ao aumento da escolaridade.

Primeiramente, ao que tudo indica, o controle do uso da variante pré-verbal respeitando os contextos em que ela seria preferida na variedade europeia decorreria do maior contato e aprendizagem do Português. O grau do conhecimento formal das regras influenciaria diretamente na fala.

Tabela 9 Aplicação da próclise em construções com uma só forma verbal de acordo com a variável Escolaridade no PM - Corpus Moçambique

\begin{tabular}{|l|c|c|c|}
\hline \multicolumn{1}{|c|}{ ESCOLARIDADE } & VALOR ABSOLUTO & PERCENTUAL & PESO RELATIVO \\
\hline Ensino fundamental & $35 / 49$ & $71.4 \%$ & .51 \\
\hline Ensino médio & $3 / 59$ & $72.9 \%$ & .69 \\
\hline Ensino superior & $28 / 45$ & $62.2 \%$ & .24 \\
\hline
\end{tabular}

De acordo com os resultados obtidos, o nível de escolaridade elevado faz com que o falante produza menos a próclise. Em termos relativos, aumenta a tendência à próclise do fundamental (.51) para o médio (.69), enquanto o curso superior funciona como um dos elementos que desfavoreceria a variante (.24). Em termos qualitativos, espera-se que estruturas com próclises em contextos sem elementos proclisadores seriam mais prováveis na fala de indivíduos menos escolarizados, como o que produziu o exemplo 54. 
Ex. 54: eu acho que eu poderia sair eu ia ficar na minha casa eu ia criar meus filhos como minha mãe fez... minha mãe nos criou independentemente dela sem condições (PMA1M-Corpus Moçambique)

De outro lado, exemplos como o 55 reproduzem a preferência pela ênclise em contextos de clíticos antecedidos de $\mathrm{SN}$ sujeito na fala dos informantes com curso superior. Supõe-se, assim, que o conhecimento formal das regras pode influenciar a escolha da colocação pronominal.

Ex. 55: as meninas prostituem-se ou se envolvem com pessoas mais velhas e os rapazes metem-se à criminalidade juntam-se aos grandes mercados informais (PMA3M-Corpus Moçambique)

A variável Sexo também demonstrou influência sobre o fenômeno no Corpus Moçambique, conforme os índices expostos na Tabela 10.

Tabela 10 Aplicação da próclise em construções com uma só forma verbal de acordo com a variável Sexo do informante no PM - Corpus Moçambique

\begin{tabular}{|l|c|c|c|}
\hline \multicolumn{1}{|c|}{ SEXO DO INFORMANTE } & VALOR ABSOLUTO & PERCENTUAL & PESO RELATIVO \\
\hline Homem & $40 / 65$ & $61.5 \%$ & .30 \\
\hline Mulher & $66 / 88$ & $75 \%$ & .64 \\
\hline
\end{tabular}

Os resultados ora apresentados apontam o favorecimento da próclise pelas mulheres (.64), em comparação aos homens (.30). Conforme já se advertiu quanto aos resultados obtidos para o PST, a interpretação do comportamento dessa variável não pode ser seguramente feita sem aprofundamento quanto ao papel da mulher na sociedade em questão. Em termos sociais, a mulher da capital Maputo, ao que parece, é bastante ativa no mercado de trabalho, assumindo, muitas vezes, a responsabilidade financeira da casa; ocorre que só um estudo aprofundado do perfil feminino permitirá investigar o comportamento da variável. Ademais, é preciso aprofundar a análise observando os contextos morfossintáticos em questão do ponto de vista estrutural: de um lado, a preferência da próclise pelas mulheres pode estar relacionada ao maior grau de atenção ao efeito das partículas proclisadoras; de outro, esse resultado pode se relacionar ao não domínio das regras estruturais e à produção da variante pré-verbal independentemente dos chamados fatores de próclise.

Além da escolaridade e do sexo dos informantes, a variável referente ao Estatuto da Língua Portuguesa para o falante - se ele a declara como sua língua materna ou não - também se mostrou relevante ao condicionamento da ordem dos clíticos pronominais. Vieira (2002) atribuiu, por hipótese, certa tendência à 
generalização da ênclise na variedade moçambicana ao aprendizado do Português como segunda língua.

Tabela 11 Aplicação da próclise em construções com uma só forma verbal de acordo com a variável Estatuto da Língua Portuguesa no PM - Corpus Moçambique

\begin{tabular}{|l|c|c|c|}
\hline EStATUto da Língua PORTUGUESA & VALOR ABSOLUTO & PERCENTUAL & PESO RELATIVO \\
\hline Primeira língua & $84 / 106$ & $79.2 \%$ & .59 \\
\hline Segunda língua & $22 / 47$ & $46.8 \%$ & .29 \\
\hline
\end{tabular}

Embora não seja possível propor generalizações, dada a pequena quantidade de dados ora em análise, chama a atenção a seleção dessa variável como relevante ao condicionamento do fenômeno. Segundo os resultados obtidos, os falantes de Português como língua materna realizaram próclise em $79.2 \%$ dos dados (.59), enquanto os informantes que se caracterizaram como falantes de Português como segunda língua realizaram a variante em $46.8 \%$ dos dados (.29), o que sugere desfavorecimento da próclise e possível uso mais geral de ênclise, conforme se observou no comportamento da variável Presença de elemento proclisador.

\section{O ESTATUTO DA ORDEM DOS CLÍTICOS NAS VARIEDADES DA LÍNGUA PORTUGUESA}

Com base em diversos trabalhos a respeito do tema da colocação pronominal e nos resultados apresentados no presente artigo, é possível sistematizar os resultados e refletir sobre a possível interpretação quanto ao perfil gramatical de cada variedade do Português sob análise.

No que se refere às construções com uma só forma verbal, o PE apresenta a variante enclítica nos contextos início absoluto de oração, após sujeito, conjunções coordenativas, expressões adverbiais, dentre outros elementos não proclisadores, mas a variante pré-verbal é a mais produtiva - embora não categórica - nos casos em que há elementos proclisadores. Nos dados do PB, do PST e do PM, entretanto, verificam-se ao menos dois padrões diferentes de colocação dos clíticos pronominais: enquanto no $\mathrm{PB}$ a regra é semicategórica, verifica-se, no PST e no PM, uma regra variável com graus de aproximação ao modelo europeu distintos.

No PB, não há efetiva variação, uma vez que a colocação foi predominantemente proclítica, independentemente do ambiente sintático em que o clítico se encontra. Os poucos dados de ênclise ocorreram com determinados pronomes átonos (sobretudo o e variantes, e se indeterminador) e em estruturas específicas. 
A variedade são-tomense utiliza, em contextos não marcados, mais a variante enclítica do que a proclítica. Destaca-se que a colocação do clítico no início absoluto de oração foi categoricamente pós-verbal, igual à registrada no PE. Os resultados acompanham, em geral, a tendência europeia de colocação, mas não seguindo com o mesmo rigor as regras que imporiam a ordem pré-verbal. Assim, não há uma nítida dicotomia entre elementos proclisadores versus elementos não proclisadores, como ocorre no $\mathrm{PE}$ (com certa variação), mas certa oscilação na colocação em mesmos contextos sintáticos. Além disso, a colocação proclítica ocorreu, por vezes, com elementos antecedentes não considerados proclisadores (como tipicamente ocorre no $\mathrm{PB}$ ), como, por exemplo, com sujeitos e conjunções coordenativas.

No PM, de forma semelhante ao registrado no PST, também se constata uma regra variável, com preferência pela ênclise em contextos não marcados e a atuação de certas partículas como proclisadoras. Nesse quadro geral, entretanto, entende-se que a instabilidade no comportamento da regra variável na variedade moçambicana é ainda maior do que a registrada na são-tomense. Ao mesmo tempo em que o efeito proclisador é verificado nos dados, é fato que se registram ocorrências não observadas - como a próclise em início de oração - ou não produtivas - como após sujeitos pronominais, por exemplo - no PE.

No que diz respeito aos complexos verbais, a análise dos dados do PE revela que há variação nos complexos formados pelas três formas de verbo principal, não tendo ocorrido a efetiva próclise a v2. Em complexos com infinitivo, ocorrem as posições proclítica a v1, enclítica a v1 e a v2, enquanto, no gerúndio e no particípio, a variação foi registrada somente entre as duas primeiras, a próclise ou a ênclise a v1.

Em relação às demais variedades - neste caso, foram considerados apenas PB e PST -, há tipos de regra específicos para cada uma delas.

Em dados brasileiros de complexos verbais, assim como nas construções com uma só forma verbal, não se verificou efetiva regra variável, tendo em vista que a colocação entre as duas formas verbais - interpretada, aqui, como próclise a v2, em função do comportamento assumido nos contextos com elementos intervenientes - constitui a opção preferencial. Os poucos dados com a colocação proclítica a v1 e enclítica a v2, sobretudo nos complexos com infinitivo, ocorrem apenas com determinados pronomes e estruturas.

No PST, ocorrem as mesmas posições realizadas no PE com os verbos no infinitivo (próclise ou ênclise a v1 e ênclise a v2), gerúndio e particípio (proclítico ou enclítico a v1), mostrando variação com os três tipos de verbos principais. De todo modo, chama atenção a ocorrência de clíticos adjacentes a v2 não somente após ter quelde, como ocorre no PE, mas também após a preposição a e o vocá- 
bulo até entre as duas formas verbais, estruturas cuja explicação merece ser aprofundada em estudos futuros que permitam observar maior número de dados com complexos verbais e em maior diversidade de estruturas.

A partir dos resultados ora sintetizados, seja nas construções com uma só forma verbal, seja nos complexos verbais, há que se refletir sobre a formação de cada variedade do Português:

(i) O Português do Brasil

$\mathrm{Na}$ variedade brasileira, cujos padrões gramaticais já estão sedimentados ou fixados, trabalhos de natureza diacrônica (cf. PAGOTTO, 1992; MARTINS, 1994; MARTINS, 2009; e NUNES, 2009; 2014) demonstram que, durante todo o processo de edificação da língua, foram observados diversos momentos de variação. Assim, no século XVI, época em que os portugueses chegaram ao Brasil, constituiria a opção preferencial a realização da variante proclítica (em todos os contextos, exceto em início absoluto de oração); no século XVII, teria começado uma mudança nos padrões de colocação pronominal, de modo que PE e PB tomaram rumos diferenciados. Resultou dessa história que, enquanto o PE passou a restringir a variante proclítica aos contextos com proclisador, o PB continuou utilizando a variante proclítica e até generalizou seu uso, empregando-a inclusive em início absoluto de oração.

Muito debate já se empreendeu a respeito das motivações para essa alteração gramatical, dentre as quais avulta a hipótese relacionada aos padrões rítmicos brasileiros, em oposição aos portugueses, de modo que o clítico pronominal, fonologicamente, seria uma partícula que se apoiaria, em termos de ligação fonológica, a enunciados tônicos à direita, enquanto no PE o padrão ocorreria em direção à esquerda (cf. VIEIRA, 2002; CORRÊA, 2012; VIEIRA; CORRÊA, 2017). Essa suposta ligação do PB para a direita fica bem nítida em dois aspectos: (i) no fato de haver próclise em início absoluto na variedade brasileira e após elementos não proclisadores; e (ii) no caso dos complexos verbais, no fato de haver a próclise a v2.

De acordo com diversos estudos sobre o tema ${ }^{14}$, estaria na base do encaixamento dessa mudança o fato de o PB ter se diferenciado do PE em função da redução das vogais átonas europeias (século XVII) com consequentes alterações no padrão rítmico. Assim, as partículas átonas desencadeariam a cliticização à esquerda, fazendo com que a ênclise se tornasse a colocação mais geral e a variante pré-verbal se apoiasse igualmente à esquerda nos chamados

14 Motivações extralinguísticas para essa mudança gramatical não estão efetivamente descartadas, mas carecem de resultados científicos até o momento. 
elementos proclisadores ${ }^{15}$. No $\mathrm{PB}$, no entanto, variedade em que essa redução das vogais átonas não ocorreu, a cliticização fonológica do pronome átono fortaleceria sua ligação à direita. Dessa forma, a próclise pôde ser generalizada, passando a ocorrer inclusive em início absoluto de oração. O parâmetro de colocação pronominal brasileiro resultante de todo esse processo pode ser verificado claramente nos resultados sintetizados no presente trabalho, que mostrou que não há efetivamente variação na modalidade oral, uma vez que a regra se revelou semicategórica com preferência pela próclise em todos os contextos.

(ii) O Português de São Tomé

No que se refere à variedade são-tomense, os padrões locais da Língua Portuguesa - embora utilizada como L1 pela maioria das pessoas - ainda não parecem estar totalmente consolidados. É certo que o intenso contato interlinguístico, em especial a convivência com um dos crioulos de base portuguesa, o Forro, também utilizado pela maioria da população, colabora para essa instabilidade na fixação dos padrões de colocação pronominal.

Em termos de tendências gerais, é nítida a preferência pelos padrões europeus de colocação, sendo a ênclise categórica, por exemplo, em início absoluto de oração. Embora a colocação seja sensível à ação de elementos no contexto antecedente ao clítico, não há uma efetiva polaridade entre elementos proclisadores versus não proclisadores; o que há é uma tendência à variante pré-verbal mediante a atuação de proclisadores, mas também a realização da ênclise nos mesmos contextos sintáticos, situação que acontece em dados do PE em proporções comparativamente muito reduzidas. Associados a essa instabilidade da atuação dos elementos proclisadores, registram-se alguns dados compatíveis com os usos brasileiros, como, por exemplo, o uso de próclise após sujeito e conjunções coordenativas.

Com os complexos verbais, essa oscilação também ocorre, porém de forma bem menos evidente. Embora, de modo geral, as tendências também sejam semelhantes às verificadas no $\mathrm{PE}$, chama atenção, nos contextos com elementos proclisadores, a variação entre ocorrências de próclise a v1, ênclise a v1 e a v2 - enquanto no PE a alternância ocorreu prototipicamente apenas entre próclise a v1 e ênclise a v2. Ademais, algumas poucas ocorrências de clítico após a preposição $a$, em estruturas aspectuais, e uma única após até - o que não se registra no PE -

15 Segundo Martins (1994), essa alteração paramétrica no PE estaria relacionada à chamada categoria sigma. Nesse nível sintático, haveria inicialmente a regulação da modalidade frasal, negativa ou afirmativa, o que se correlacionaria a alterações relacionadas a outras opções gramaticais, segundo o aporte da teoria gerativa, e, em última análise, afetaria a ordem dos clíticos. 
deixam dúvida quanto à possibilidade de o clítico do PST estar associado em próclise a v2.

(iii) O Português de Moçambique

Considerando um continuum de maior ou menor proximidade dos dados com o PB ou com o PE, a variedade moçambicana permite postular maior afastamento da norma que teoricamente lhe serve de referência, a europeia.

Em termos linguísticos, embora os presentes resultados sejam preliminares, eles sugerem uma particularidade ainda mais clara no quadro estrutural da Língua Portuguesa em formação na variedade moçambicana. Aparentemente, a variedade em questão estaria estabelecendo suas feições ancoradas na instabilidade de colocação, visto que, em alguns contextos, segue as tendências conhecidas na variedade europeia (como o efeito proclisador ou não proclisador, de modo geral) e em outros chega a registrar ocorrências não observadas na variedade europeia (nem na são-tomense), mas típicas da variedade brasileira, como a presença de próclise em início de oração ou a preferência absoluta por essa variante após sujeitos pronominais, por exemplo. A força dos condicionamentos extralinguísticos, como os relacionados a escolaridade, sexo, estatuto da língua materna, também advoga em favor da especificidade do PM.

A dimensão da instabilidade moçambicana foi registrada no estudo pioneiro de SEMEDO (1997), quando atesta, na sintaxe moçambicana, "entre outros aspectos, uma grande liberdade no uso dos pronomes pessoais objecto átonos (clíticos).” (p. 8). O autor propõe que, embora o Português utilizado em Moçambique siga, oficialmente, a norma europeia, ocorrem particularidades evidentes:

no que concerne ao domínio de colocação dos pronomes pessoais clíticos, os inquiridos seguem a norma do português padrão em $50 \%$ dos casos, enquanto o grupo de controle [falantes lisboetas] o faz em 92\% (...) (SEMEDO, 1997, p. 32).

Embora a investigação dos dados de entrevistas recentes, como as do Corpus Moçambique, ainda esteja em estágio inicial, o que se verificou nas análises apresentadas pode ser um possível reflexo da particular situação de multilinguismo e do estatuto do Português como L2 em Moçambique, apontando a configuração de padrões próprios dessa variedade. Assim, os resultados ora apresentados indicam a necessidade de estudos aprofundados dos fenômenos variáveis em uso por moçambicanos, de modo a conseguir identificar raízes das possíveis mudanças e sinais de que essa variedade do Português já esteja prestes a assumir um perfil próprio, assim como aconteceu com a variedade brasileira.

Os resultados do estudo vão ao encontro da hipótese de que o estatuto de língua aprendida (L2) do PM para muitos falantes (em uma sociedade cuja histó- 
ria de opressão se ressente da defesa de seus próprios elementos culturais) possa estar relacionado ao caráter hesitante da expressão linguística. Essa espécie de 'conflito' no uso da língua foi apreendida, com mestria, pelo escritor moçambicano, em suas sábias palavras:

O português moçambicano - ou ainda, nesta altura, o português em Moçambique - é ele próprio um lugar de conflitos e ambiguidades. A adesão moçambicana à lusofonia está carregada de reservas, aparentes recusas, desconfiadas aderências. O que eu gostaria de mostrar aqui é esse caminho em zig-zag que não resulta de capricho dos dirigentes, mas de ambivalências da História. (MIA COUTO, 2002) ${ }^{16}$

\section{REFLEXÕES FINAIS: AS PARTICULARIDADES DAS VARIEDADES AFRICANAS DO PORTUGUÊS}

Com base na descrição dos dados do Português de São Tomé e do Português de Moçambique, cabem algumas reflexões finais a respeito das particularidades da colocação pronominal verificadas nessas variedades.

De um lado, o forte alinhamento das variedades africanas com os padrões de colocação europeus pode ser claramente relacionado à influência direta do processo de colonização tanto em São Tomé e Príncipe quanto em Moçambique. Desse modo, é mais do que natural que a norma que venha a servir de referência, em ambos os casos, seja a europeia, sobretudo se for considerada a situação de aprendizagem formal de Português como L2 nos bancos escolares. A esse respeito, é preciso, sem dúvida, investir em pesquisas que investiguem o perfil do professor, do material didático escolar e dos métodos de ensino de Português como L2, para que seja possível aquilatar melhor a influência do PE na aprendizagem formal da língua.

De outro lado, as particularidades verificadas no PST e no PM - dentre as quais se destacam, no âmbito do presente artigo, as relacionadas à ordem dos clíticos pronominais - necessitam ser explicadas à luz de hipóteses de ordem linguística e/ou extralinguística.

As motivações internas à própria língua para justificar os padrões de colocação pronominal diferentes entre PB e PE foram propostas mediante a soma de resultados de vasta pesquisa sincrônica e diacrônica, o que não seria possível

16 As palavras ora citadas constituem trecho de sua palestra, intitulada "Luso-afonias - a lusofonia entre viagens e crimes”, proferida no IV Seminário das lusografias, realizado em Maputo, de 18 a 22 de fevereiro de 2002, a ser publicada nas Actas do IV Seminário das Lusografias. 
propor nos limites do presente artigo. Ainda assim, essas explicações ficaram restritas a motivações de ordem sintática e de natureza rítmica.

Considerando, então, motivações de natureza externa, ao menos duas hipóteses explicativas podem ser apresentadas: (i) as particularidades verificadas adviriam da influência direta de um substrato; e (ii) as particularidades resultariam da situação de intenso contato linguístico típico das sociedades em questão, o que acabaria por gerar inputs distintos para aquisição do Português.

No caso das variedades africanas, a falta de conhecimento aprofundado do Forro (língua crioula mais falada em São Tomé) e do Changana (língua banto mais falada em Maputo) não permite, nos limites deste artigo, maior debate acerca da primeira dessas hipóteses.

Vieira (2016), entretanto, de posse da descrição de características do Forro, de acordo com Ferraz (1979) e Hagemeijer (2007), afirma que o crioulo utilizaria os pronomes objetos, geralmente, na posição pós-verbal. Assim sendo, a influência do Forro não explicaria as diversas ocorrências da variante pré-verbal no PST. Desse modo, a motivação da instabilidade na colocação dos clíticos verificada no PST e, de forma ainda mais intensa, no PM, embora pareça estar relacionada à situação de intenso contato com diversas línguas, carece de investigação aprofundada e específica.

Sem dúvida, os resultados dos estudos reunidos no presente texto somam-se à interpretação feita por pesquisadores que têm defendido a tese de que o contato entre línguas distintas constitua forte motivação para as configurações das variedades não nativas de línguas coloniais (LUCCHESI; BAXTER; RIBEIRO, 2009, por exemplo). A respeito do comportamento específico do PST, declara, também, Gonçalves (2009):

(...) a variação entre próclise e ênclise nos mesmos contextos sintácticos é frequente no Português Oral de S. Tomé. Este facto é típico de uma variedade de língua que, embora actualmente comece a afirmar-se como língua materna, foi adquirida como língua segunda. (...) Aquilo que os dados dos clíticos nos mostram é que, muito provavelmente, o português de S. Tomé constitui uma interlíngua ainda não fossilizada pelo que a variação nas mesmas estruturas não nos permite caracterizar o sistema de colocação dos clíticos mas tão-somente descrevê-lo o mais pormenorizadamente possível procurando entrever aquilo que pode vir a constituir uma idiossincrasia do seu sistema linguístico. (GONÇALVES, 2009, p. 22)

Assim, no caso do PST, a oscilação presente nos mesmos ambientes sintáticos seria favorecida por dois fatores: (i) de um lado, as influências para a constituição do PST favoreceriam a opção pós-verbal, seja pelo contato com o Forro, 
direta ou indiretamente, seja pelo modelo europeu de colocação, que apresenta a ênclise como ordem não marcada; e (ii) de outro lado, pelo fato de ainda não se ter uma variedade são-tomense consolidada, a aquisição do modelo com efeito proclisador ainda não estaria estabelecida plenamente, de modo que ocorreria ora próclise, ora ênclise nos mesmos contextos sintáticos.

Estendendo a reflexão aos dados do PM, que se afastariam, ainda mais, das regras europeias de colocação, propõe-se que as tendências verificadas quanto à posição dos clíticos pronominais estejam vinculadas à própria história de formação dessa variedade, ainda em curso. Ao que tudo indica, o PM adotou inicialmente a opção preferencial da língua do colonizador: a ênclise como ordem não marcada, bem como a maioria dos condicionamentos sintáticos do PE; entretanto, não se submeteu plenamente às mesmas regras, havendo, assim, a referida instabilidade na utilização dos clíticos pronominais.

Comparando PM e PST, a maior ou menor distância das regras de uso de cada variedade em relação ao modelo europeu também pode estar relacionada ao estatuto do Português em cada uma dessas variedades. Sendo o Português L1 para a maioria dos falantes são-tomenses e L2 para a maioria dos moçambicanos, justificam-se as maiores particularidades bem como maior oscilação no uso da ordem dos clíticos no PM do que no PST, estando o primeiro, ao que parece, mais propenso à implementação da variante pré-verbal em contextos diversos.

A respeito da influência do contato multilinguístico e da aprendizagem instável do Português, convém uma reflexão adicional: considerando o Princípio do Uniformitarismo, o que a realidade do PST e do PM poderia revelar sobre a formação do PB? Como no Português do Brasil, na época da formação de suas especificidades, havia também diversos parâmetros linguísticos em contato, é bastante razoável propor que as características, sobretudo as relacionadas à instabilidade da formação da nova língua, eram semelhantes - resguardadas as dimensões - às verificadas nas realidades são-tomense e moçambicana.

Ao que parece, a situação de multilinguismo no Brasil pode ter exercido fundamental influência quanto aos padrões de colocação pronominal que, ao longo do tempo, resultaram em forte parâmetro diferenciador entre PB e PE. A próclise, recebida na colonização, teria se fixado como tendência, seja por possíveis padrões rítmicos ou estruturais relacionados às línguas bantas aqui faladas - o que o presente trabalho não pode afirmar, visto que não desenvolveu esse tópico como objeto de estudo -, seja pela instabilidade natural do comportamento linguístico em situações de intenso contato. Em diferentes medidas e direções, motivações sócio-históricas semelhantes podem estar relacionadas ao fato de que a língua dos países colonizados se distancie e utilize parâmetros de colocação diferentes da língua do país colonizador. Para que essa interpretação seja seguramente tratada, 
entende-se ser necessária uma investigação específica e detalhada, como o fez Ferraz (1979) para o Forro, das línguas faladas em Moçambique e em São Tomé, e das que existiam no Brasil e que conviveram durante muitos séculos com a Língua Portuguesa.

De todo modo, as descrições da ordem dos clíticos pronominais no PB, PE, PST e PM ora propostas permitem delinear as diferenças entre as quatro variedades, que já podem ser percebidas. Primeiramente, a oposição mais evidente é a do $\mathrm{PB}$ contra o PE, diferença quantitativa e qualitativamente comprovada. Nesse sentido, particularizam o primeiro os contextos de início absoluto de oração com próclise - e de complexos verbais - com próclise a v2, permitindo estabelecer a adoção de um parâmetro absolutamente particular para a variedade brasileira. Em segundo plano, o PST e o PM - em diferentes medidas - particularizam-se quanto às demais variedades por, de um lado, se assemelharem ao PE, adotando preferencialmente as mesmas variantes nos contextos aqui destacados e aplicando tendências de uso consoante o efeito proclisador; de outro lado, entretanto, apresentam quantitativamente uma escala gradual desse efeito e não uma efetiva delimitação dos contextos de próclise e de ênclise. Ademais, qualitativamente, verificam-se dados de próclise nas duas variedades africanas em contextos que seriam de ênclise na variedade europeia.

Embora ainda sem condições de propor generalizações seguras, o presente artigo reafirma o necessário caminho para ampliar a reflexão sobre a formação do $\mathrm{PB}$ e das demais variedades do Português, que se afigura como de extrema importância. Sem dúvida, o estudo da colocação pronominal e de outros temas em diversas variedades da Língua Portuguesa, em especial nas que ainda estão, em diferentes medidas, em constituição, como o Português de São Tomé, de Moçambique, de Angola, entre outras, é fundamental para a compreensão do que ocorre não só com as variedades transplantadas, mas também, indiretamente, do que supostamente ocorreu com a formação do Português do Brasil. Desse modo, a proposta de um continuum afro-brasileiro possivelmente será sustentada, não como uma tese aprioristicamente definida, mas como uma consequência natural do conhecimento acerca das variedades do Português em relação a cada regra linguística, e em diversos níveis gramaticais, empreendimento de que resulta a publicação do presente livro.

\section{REFERÊNCIAS}

AVELAR, Juanito; GALVES, Charlotte. O papel das línguas africanas na emergência da gramática do português brasileiro. Linguística, 30 (2), p. 241-288, 2014.

BRANDÃO, Silvia Figueiredo. Concordância nominal em duas variedades do Português: Convergências e divergências. Revista Veredas, 15 (1), p. 164-178, 2011. 
CORRÊA, Cristina Márcia Monteiro de Lima. Cliticização pronominal na região metropolitana do Rio de Janeiro: a interface Sintaxe-Fonologia. 2012. Dissertação (Mestrado em Letras Vernáculas) - Faculdade de Letras, Universidade Federal do Rio de Janeiro, Rio de Janeiro, 2012.

FERRAZ, Luis Ivens. The Creole of São Tomé. Johannesburg: Witwatersrand University Press, 1979.

GONÇALVES, Perpétua. A gênese do Português de Moçambique. Lisboa: INCM, 2010. GONÇALVES, Perpétua; STROUD, Christopher (Org.). Panorama do Português oral de Maputo: objetivos e métodos. Maputo: Instituto Nacional do Desenvolvimento da Educação, 1997. v. I (Cadernos de pesquisa do Inde n. 22).

GONÇALVES, Perpétua; STROUD, Christopher (Org.). Panorama do Português oral de Maputo. v. III; Estruturas gramaticais do Português: problemas e exercícios. Maputo: Instituto Nacional do Desenvolvimento da Educação, 1998 (Cadernos de pesquisa do Inde n. 27).

GONÇALVES, Perpétua; MORENO, Albertina; TUZINE, António; DINIZ, Maria João; MENDONÇA, Marisa. Estruturas gramaticais do Português: problemas e exercícios. Pronomes pessoais. In: GONÇALVES, Perpétua; STROUD, Christopher (Org.). Panorama do Português oral de Maputo. v. III; Estruturas gramaticais do Português: problemas e exercícios. Maputo: Instituto Nacional do Desenvolvimento da Educação, 1998. p. 59-87 (Cadernos de pesquisa do Inde n. 27).

GONÇAlVES, Rita. A Colocação dos Pronomes Clíticos no Português Oral de S. Tomé: Análise e discussão de contextos numa perspectiva comparativa. 2009. Dissertação (Mestrado) - Universidade de Lisboa, Lisboa, 2009.

HAGEMEIJER, Tjerk. As línguas de São Tomé e Príncipe. Revista de Crioulos de Base Lexical Portuguesa e Espanhola, 1 (1), p. 1-27, 2009.

LABOV, William. Sociolinguistic patterns. Philadelphia: University of Pennsylvania Press, 1972.

LABOV, William. Some sociolinguistic principles. In: PAULSTON, Christina Bratt; TUCKER, G. Richard (Eds.). Sociolinguistics: the essential readings. Blackwell Publishing, 2003. p. 234-250.

LOBO, Tânia. A colocação dos clíticos em Português: duas sincronias em confronto. 1992. Dissertação (Mestrado) - Universidade de Lisboa, Lisboa, 1992.

LUCCHESI, Dante; BAXTER, Alan; RIBEIRO, Ilza. O português afro-brasileiro. Salvador: EDUFBA, 2009.

MARTINS, Ana Maria. Clíticos na história do Português. 1994. Tese (Doutorado) Universidade de Lisboa, Lisboa, 1994.

MARTINS, Ana Maria. Posição dos pronomes pessoais clíticos. In: RAPOSO, Eduardo; NASCIMENTO, Maria Fernanda; MOTA, Maria Antónia; SEGURA, Luísa; MEN- 
DES, Amália (Org.). Gramática do Português. Lisboa: Fundação Calouste Gulbenkian, 2013. p. 2231-2302.

MARTINS, Marco Antônio. Competição de gramáticas do português na escrita catarinense dos séculos 19 e 20. 2009. Tese (Doutorado) - Universidade Federal de Santa Catarina, Florianópolis, 2009.

NUNES, Carla da Silva. Um estudo sobre a ordem dos clíticos em complexos verbais no PB e no PE. 2009. Dissertação (Mestrado em Letras Vernáculas), Faculdade de Letras, Universidade Federal do Rio de Janeiro, Rio de Janeiro, 2009.

NUNES, Carla da Silva. A ordenação do clítico "se" em complexos verbais nas produções escritas do Brasil e de Portugal nos séculos XIX e XX segundo a perspectiva sociolinguística. 2014. Tese (Doutorado em Letras Vernáculas) - Faculdade de Letras, Universidade Federal do Rio de Janeiro, Rio de Janeiro, 2014.

NUNES, Jairo. Direção de cliticização, objeto nulo e pronome tônico na posição de objeto em Português Brasileiro. In: ROBERTS, Ian; KATO, Mary (Org.). Português Brasileiro: uma viagem diacrônica. Campinas: Editora da UNICAMP, 1993. p. 207-222.

PAGOTTO, Emílio Gozze. A posição dos clíticos em Português: um estudo diacrônico. 1992. Dissertação (Mestrado), UNICAMP, Campinas, SP, 1992.

PETTER, Margarida Maria Taddoni. Uma hipótese explicativa do contato entre o português e as línguas africanas. Papia, 17, p. 9-19, 2007.

PETTER, Margarida Maria Taddoni. Ampliando o continuum afro-brasileiro de português. Papia: Revista Brasileira de Estudos Crioulos e Similares, v. 25, p. 305-317, 2015. SEMEDO, Manuel Brito. A colocação dos clíticos no Português em Maputo. Maputo: Instituto Nacional do Desenvolvimento da Educação, 1997. (Cadernos de pesquisa do Inde no 25)

VIEIRA, Maria de Fátima. A ordem dos cliticos pronominais nas variedades urbanas europeia, brasileira e são-tomense: uma análise Sociolinguística do Português no início do século XXI. 2016. Tese (Doutorado em Língua Portuguesa) - Faculdade de Letras, Universidade Federal do Rio de Janeiro, Rio de Janeiro, 2016.

VIEIRA, Silvia Rodrigues. Colocação pronominal nas variedades europeia, brasileira e moçambicana: para a definição da natureza do clítico em Português. 2002. Tese (Doutorado em Língua Portuguesa) - Faculdade de Letras, Universidade Federal do Rio de Janeiro, Rio de Janeiro, 2002.

VIEIRA, Silvia Rodrigues. Entre o variável e o categórico: a concordância verbal e a colocação pronominal em variedades do Português. In: REZENDE, Letícia; SILVA, Odair Luiz; MENDONÇA, Marina Célia; ZAVAGLIA, Claudia; BRUNELLI, Anna Flora (Org.). A interdisciplinaridade e a especificidade linguística: teorias e práticas. Araraquara; FCL-UNESP Laboratório Editorial; São Paulo: Cultura Acadêmica, 2014. p. $75-98$. 
VIEIRA, Silvia Rodrigues; BRANDÃO, Silvia Figueiredo. Tipologia de regras linguísticas e estatuto das variedades/línguas: A concordância em português. Linguística 30, p. 81-112, 2014.

VIEIRA, Silvia Rodrigues; CORRÊA, Cristina Márcia Monteiro de Lima. Colocação pronominal no Português do Brasil: a contribuição de estudos de percepção auditiva. Letras de Hoje, Porto Alegre, v. 52 (1), p. 87-96, 2017.

WEINREICH, Uriel, LABOV, William; HERZOG, Marvin I. Empirical foundations for theory of linguistic change. In: LEHMANN, Winfred P.; MALKIEL, Yakov (Org.). Directions for historical linguistics. Austin: University of Texas Press, 1968. p. 97-195. 